\title{
EL DERECHO A LA PROPIA IMAGEN DE LOS PERSONAJES PÚBLICOS EN LAS JURISPRUDENCIAS CONSTITUCIONAL, ORDINARIA Y EUROPEA. EVOLUCIÓN, CONCORDANCIAS Y DIVERGENCIAS
}

\author{
MARÍA DEL MAR NAVAS SÁNCHEZ
}


SUMARIO

1. INTRODUCCIÓN. 2. LA ESCASA, PERO ADECUADA, INFLUENCIA EXPRESA DEL CANON EUROPEO EN LA PRIMERA ETAPA DE LA JURISPRUDENCIA CONSTITUCIONAL SOBRE EL DERECHO FUNDAMENTAL A LA PROPIA IMAGEN. 3. EL DERECHO FUNDAMENTAL A LA PROPIA IMAGEN DE LOS PERSONAJES PÚBLICOS EN LA JURISPRUDENCIA CONSTITUCIONAL ANTERIOR A LA STC 19/2014. SU CASI NULA ASUNCIÓN POR EL TRIBUNAL SUPREMO. 4. EL DERECHO FUNDAMENTAL A LA PROPIA IMAGEN DE LOS PERSONAJES PÚBLICOS EN LA ÚLTIMA JURISPRUDENCIA DEL TRIBUNAL CONSTITUCIONAL. SU - AHORA SÍ- RECEPCIÓN POR EL TRIBUNAL SUPREMO. 5. LA RELACIÓN DE LA JURISPRUDENCIA CONSTITUCIONAL CON LA DEL TRIBUNAL EUROPEO DE DERECHOS HUMANOS SOBRE ESTE DERECHO VISTA A TRAVÉS DE LA STC 19/2014. 6. CONCLUSIONES. 


\title{
EL DERECHO A LA PROPIA IMAGEN DE LOS PERSONAJES PÚBLICOS EN LAS JURISPRUDENCIAS CONSTITUCIONAL, ORDINARIA Y EUROPEA. EVOLUCIÓN, CONCORDANCIAS Y DIVERGENCIAS ${ }^{1}$
}

\author{
MARÍA DEL MAR NAVAS SÁNCHEZ
}

Profesora Titular de Derecho Constitucional ${ }^{2}$

\section{INTRODUCCIÓN}

Visto desde hoy, con la perspectiva que otorgan los cuarenta años transcurridos desde la promulgación de la Constitución en 1978 y la constatación de la importancia creciente que la imagen tiene cada vez más en las sociedades actuales, bien pudiera afirmarse de nuestra Constitución su carácter pionero, al otorgar a la protección de la propia imagen, sin precedentes en nuestro entorno que lo avalaran ${ }^{3}$, el estatus de un auténtico derecho fundamental autónomo, diferen-

1 Durante la elaboración de este trabajo he tenido la oportunidad de debatirlo con la profesora María Luisa Balaguer y con el profesor Ángel Rodríguez. A ambos deseo agradecer sus, como siempre, valiosas e inestimables sugerencias y comentarios.

2 Universidad de Málaga. Facultad de Derecho. Bulevar Luis Pasteur, 26. 29071. Málaga. Email: navas@uma.es

3 En efecto, ni en la Declaración Universal de Derechos Humanos ni el Pacto Internacional de Derechos Civiles y Políticos ni, muy especialmente por su importancia para nosotros, en el Convenio Europeo para la Protección de los Derechos Humanos y de las Libertades Fundamentales (en adelante, $\mathrm{CEDH}$ ) la propia imagen es objeto de un reconocimiento explícito y diferenciado, sino dentro de la más amplia protección de la vida privada (art. 8.1 CEDH). Tampoco en las 
ciado de los restantes llamados de la personalidad y muy especialmente del derecho a la intimidad.

Esta autonomía ha permitido reconocer a este derecho un ámbito y una especificidad propia destinada a preservar un aspecto de la vida privada de las personas, de su privacidad, no cubierta, en principio, por ningún otro de los derechos que gozan de reconocimiento constitucional ${ }^{4}$. Así, por un lado, su objeto se contrae a la protección, no de cualquier imagen de la persona, sino tan solo de su imagen física, esto es, de sus rasgos físicos personales ${ }^{5}$. Por otro, no se requiere, para que opere la protección anudada a este derecho, que la imagen en cuestión muestre a la persona en una situación desfavorable que pudiera afectar a su derecho al honor ni tampoco que desvele aspecto alguno de su vida privada protegida por el derecho a la intimidad. Basta con que la persona sea recognoscible, es decir, que aparezca identificada o pueda serlo y que no haya prestado su consentimiento para la captación y/o publicación de la misma. Esto es justamente lo específico del derecho a la imagen y que justifica su protección iusfundamental como un derecho autónomo y diferenciado: otorgar protección frente a toda captación y/o difusión inconsentida de la imagen de una persona ${ }^{6}$, aun cuando esta sea totalmente inocua o neutral, dado que de no serlo, por afectar a su buen nombre o mostrar parte de la intimidad del sujeto, encontraría ya protección al amparo de los derechos al honor y a la intimidad, respectivamente.

A su vez, respecto de dicho objeto, este derecho otorga a su titular la facultad principal de impedir la captación y/o difusión no consentida de su imagen ${ }^{7}$. Este es el contenido constitucional propio de este derecho, que enlaza con la idea de

Constituciones de los países de nuestro entorno, con la excepción de Portugal, cuya Constitución, tras su reforma en 1982 y por tanto después de la aprobación de nuestra Constitución, pasó a reconocer el derecho a la imagen como un derecho autónomo en su artículo 26 n. ${ }^{\circ} 1$.

${ }^{4}$ Con eficacia, además, no solo «frente a los poderes públicos, sino también frente a empresas de comunicación y, en general, a todos los ciudadanos que vendrán obligados a respetar ese espacio de reserva individual.» [Balaguer Callejón, María Luisa (2016), Derecho de la Información y de la Comunicación, 2. ${ }^{a}$ ed., Madrid, Tecnos, p. 135].

${ }^{5}$ Lo que deja fuera de su ámbito de protección la imagen social de la persona, objeto de protección del derecho al honor.

${ }^{6}$ STC 81/2001, FJ 2. Una crítica a esta delimitación «amplísima» del derecho a la propia imagen, contenida tanto en la Ley como en la jurisprudencia del TC, en SALVAdor Coderch, Pablo, et al. (2011), «Imágenes veladas. Libertad de información, derecho a la propia imagen y autocensura de los medios», InDret, 1/2011, p. 9.

7 «En su dimensión constitucional, el derecho a la propia imagen consagrado en el artículo 18.1 CE (...) atribuye a su titular un derecho a determinar la información gráfica generada por sus rasgos físicos personales que puede tener difusión pública. La facultad otorgada por este derecho, en tanto que derecho fundamental, consiste en esencia en impedir la obtención, reproducción o publicación de la imagen por parte de un tercero no autorizado, sea cual sea la 
autodeterminación que está presente en otros tantos derechos reconocidos en el artículo 18 CE para la protección de la privacidad de la persona ${ }^{8}$. En este caso, respecto de la información gráfica generada por sus rasgos físicos personales 9 . Aquellos que lo individualizan y lo hacen recognoscible como ser humano único y diferenciado de sus congéneres.

Una facultad de consentimiento y oposición que aún hoy, a pesar de las transformaciones experimentadas por la sociedad y del surgimiento de nuevas potenciales amenazas al derecho a la imagen derivadas del desarrollo tecnológico en todos los ámbitos de la vida, sigue teniendo en su confrontación con los medios de comunicación, en la publicación de información gráfica que estos pueden hacer al amparo de las libertades informativas, una de sus vías principales de ejercicio y que, además, más decisivamente ha influido en la configuración del derecho a la propia imagen tal y como lo conocemos.

Precisamente uno de los supuestos más controvertidos en este ámbito, por las diferentes posturas mantenidas al respecto por el legislador, la jurisdicción ordinaria, particularmente el Tribunal Supremo, y el Tribunal Constitucional y sobre el que probablemente en mayor número de ocasiones se han pronunciado ambos Tribunales ha sido el relativo al alcance de este derecho cuando se trata de la difusión no consentida de la imagen de personas que pudieran ser consideradas, en un sentido amplio, como personajes públicos ${ }^{10}$. Que ha dado como resultado, a su vez, una significativa evolución no solo respecto de dicho alcance sino incluso también

finalidad - informativa, comercial, científica, cultural, etc.- perseguida por quien la capta o la difunde» (STC 81/2001, FJ 2).

8 Esta misma idea de autodeterminación en relación con el derecho fundamental a la propia imagen la encontramos en CARrILlo, Marc (1994), «El derecho a la propia imagen como derecho fundamental», Revista Jurídica de Asturias, núm. 18, p. 18.

9 En este sentido, la ampliación operada por el TC en su STC 167/2013 para acoger también el derecho al nombre bajo el ámbito de protección del derecho a la propia imagen constituye una anomalía respecto del contenido típico de este derecho, la de otorgar protección frente a toda captación y/o publicación no consentida de los rasgos físicos personales de la persona a la que se le otorga, así, la facultad de impedir tales acciones sobre su imagen.

10 Si bien desde la STC 134/1999 se suele diferenciar entre «personajes públicos» y «personajes con notoriedad pública» utilizamos la expresión aquí en un sentido amplio, comprensivo no solo de quienes ejercen un cargo público o desempeñan una actividad política sino también de aquellas personas que alcanzan cierta notoriedad o proyección pública como resultado de la actividad profesional que desarrollan o simplemente por exponer mediáticamente su vida privada. No solo el artículo 8.2.a) LO 1/1982 los equipara en lo que se refiere al derecho fundamental a la propia imagen, sino que tampoco es posible encontrar una diferencia significativa en cuanto a su tratamiento, por lo que específicamente a este derecho se refiere, en la jurisprudencia constitucional. La categoría «personaje público» vendría a contraponerse así, en el uso que aquí le damos, a la de «personas privadas o anónimas». 
respecto de la propia conceptualización del derecho a la propia imagen, de lo qué es, significa y protege; de su contenido y posición constitucional.

Así, partiendo del desarrollo legislativo que de las previsiones constitucionales (arts. 20.4 CE y 18.1 CE) se contienen en la LO 1/1982, de 5 de mayo, de protección civil del derecho al honor, a la intimidad personal y familiar y a la propia imagen; (en adelante, LO 1/1982) y más concretamente en su artículo 8.2.a) de acuerdo con el cual el derecho a la imagen no impedirá «su captación reproducción o publicación por cualquier medio, cuando se trate de personas que ejerzan un cargo público o una profesión de notoriedad o proyección pública y la imagen se capte en un acto público o en lugares abiertos al público» se ha llegado a una situación en la que lo único relevante resulta ser el interés público presente en tales imágenes. Su carácter noticiable.

Pero para ello han sido necesarias algo más de tres décadas que pueden ser contempladas no solo desde el punto de vista de la evolución a la que antes aludíamos, sino también de la interrelación que a lo largo de estos años se ha establecido entre tres de las principales jurisdicciones a las que compete la tutela de este derecho en su relación dialéctica con los medios de comunicación en nuestro sistema jurídico: la constitucional, la ordinaria y la europea; entendiendo por esta última la residenciada en el TEDH. Al análisis de ambas cuestiones se dirige este artículo. Teniendo en cuenta, además, que hemos tomado como punto de referencia o centro neurálgico de este entramado de relaciones o interconexiones jurisprudenciales a nuestro Tribunal Constitucional. Nos interesa, por tanto, abordar, de un lado, si el TC se sirve y, en su caso, la forma en que lo hace, de la jurisprudencia del Tribunal de Estrasburgo para configurar el alcance y régimen jurídico del derecho fundamental a la propia imagen, en particular cuando se trata de personajes públicos; y, de otro, el modo en que el Tribunal Supremo recepciona, si es que lo hace, esta doctrina del Tribunal Constitucional, asumiéndola y aplicándola en el caso concreto para resolver el conflicto planteado entre la propia imagen de este tipo de personas y las libertades de información y expresión.

En este sentido, es preciso destacar cómo la configuración constitucional del régimen jurídico del derecho fundamental a la propia imagen de quienes pudieran ser considerados personajes públicos frente a su difusión mediática ha venido marcada por la profunda divergencia que durante bastantes años han mantenido sobre esta cuestión el Tribunal Constitucional y el Supremo. Al menos, como se verá en las páginas que siguen, hasta fecha muy reciente y más concretamente hasta la jurisprudencia civil posterior a la STC 19/2014. Así, si bien en la actualidad puede afirmarse que esta brecha ha empezado a cerrarse, este alineamiento del TS con la doctrina del TC sobre el alcance de la protección del derecho a la propia imagen de las denominadas personas públicas frente a cualquier publica- 
ción inconsentida que, invocando la libertad de información, pudiera producirse en los medios de comunicación no es sino el resultado de un largo proceso evolutivo que iniciándose con la publicación misma de la LO 1/1982 no habría de culminar — si es que tal cosa puede afirmarse taxativamente a fecha de hoysino tras la STC 19/2014 ${ }^{11}$. De este modo, la distancia que, en punto a esta cuestión, separa a ambos Tribunales es la que media entre el artículo 8.2.a) LO 1/1982 y la recepción por el TS de la interpretación conforme a la Constitución que de este precepto legal se contiene en la STC 19/2014.

No obstante, es posible apreciar aquí, en la jurisprudencia del TC relativa al derecho fundamental a la propia imagen de este tipo de personas, dos etapas claramente diferenciadas ${ }^{12}$. La primera, representada fundamentalmente por las SSTC 139/2001 y 83/2002 y que se extenderá hasta finales de la primera-principios de la segunda década de este siglo. La segunda, residenciada en la STC 19/2014 hacia adelante. Además, estas dos etapas no solo representan, como se verá, una evolución significativa en la doctrina constitucional sobre el derecho a la propia imagen de las personas públicas en su relación dialéctica con los medios de comunicación, sino que, además, se refleja también en la forma en la que la jurisdicción ordinaria y particularmente el Tribunal Supremo se va a relacionar con esta jurisprudencia constitucional. Incluso, como tendremos oportunidad de examinar, puede ser contemplada a la luz de la incidencia que en esta doctrina del Tribunal Constitucional haya podido, o no, tener la jurisprudencia del TEDH sobre esta misma cuestión. Mínima, casi nula, en la primera etapa ${ }^{13}$. Mayor, pero de manera claramente selectiva, en la que hemos establecido como segunda. Ello no ha impedido, sin embargo, y sobre ello se volverá más adelante, una sustancial sintonía o iden-

11 En este sentido ha destacado Ángel RoDRíGUEz la influencia decisiva, incluso por encima de criterios y consideraciones de carácter constitucional, de la LO 1/1982 a la hora de resolver los posibles conflictos entre las libertades de expresión e información y el derecho a la propia imagen, que se deciden «no tanto por criterios constitucionales como por la aplicación, no mediada por éstos, de los establecidos por el legislador» [RodríGuez, Ángel (2016), El honor de los inocentes y otros límites a la libertad de expresión relacionados con la Administración de Justicia, Valencia, Tirant lo Blanch, p. 100].

12 Para un análisis más detallado de estas dos etapas, desde el punto de vista del uso que el TC hace del criterio relativo al interés público de la imagen en cuanto información gráfica, véase NAVAS SáNCHEz, M. a del Mar (2017), «El uso informativo de la imagen. Imágenes inocuas, hechos noticiables o de cuán relevante ha de ser la imagen en cuanto información gráfica», InDret, 1/2017, pp. 22-32.

13 Sobre la incidencia del canon europeo en la jurisprudencia constitucional relativa al conflicto de las libertades de expresión e información con los otros dos derechos del artículo 18.1 honor e intimidad — véase Queralt Jiménez, Argelia (2008), La interpretación de los derechos: del Tribunal de Estrasburgo al Tribunal Constitucional, Madrid, Centro de Estudios Políticos y Constitucionales, pp. 265-273. 
tidad de nuestra jurisdicción constitucional con la europea en lo que se refiere a la determinación del contenido del derecho a la propia imagen, con carácter general; no así, sin embargo, en lo que se refiere específicamente al modo de resolver el conflicto entre este derecho y las libertades de expresión y comunicación cuando de la publicación de fotografías de personajes públicos se trata.

\section{LA ESCASA, PERO ADECUADA, INFLUENCIA EXPRESA DEL CANON EUROPEO EN LA PRIMERA ETAPA DE LA JURISPRUDENCIA CONSTITUCIONAL SOBRE EL DERECHO FUNDAMENTAL A LA PROPIA IMAGEN}

Acaba de indicarse que la jurisprudencia europea apenas ha tenido incidencia en la que hemos establecido como primera etapa de la doctrina del TC sobre el derecho a la propia imagen de los denominados personajes públicos. Lo que no ha sido, sin embargo, óbice para que nuestra jurisprudencia constitucional resulte en este punto sustancialmente conforme —a los efectos del artículo 10.2 $\mathrm{CE}$ - con la del Tribunal de Estrasburgo ${ }^{14}$. Así, salvando la diferencia, que no es de importancia menor, que supone su diferente reconocimiento, bien como derecho fundamental autónomo (art. 18.1 CE) o como un aspecto del más amplio derecho a la vida privada (art. 8.1 CEDH) ${ }^{15}$, ambos Tribunales comparten una visión común acerca de aspectos clave de este derecho. En este sentido ambos han destacado la trascendental importancia que para el propio desarrollo personal, para la construcción de la personalidad tiene la imagen, el aspecto físico de la persona ${ }^{16}$. De ahí que ambos hayan enfatizado la necesidad de su protección. Protección que también en ambas jurisdicciones se contrae a otorgar a su titular el control sobre su imagen y, que comprende, por tanto, como una parte esencial de su naturaleza de derecho de defensa, la facultad de impedir tanto su divulga-

14 Como han destacado Queralt Jiménez, Argelia [(2008), ibídem., p. 200) y Saiz Arnaiz, Alejandro [(2008), «Art. 10.2. La interpretación de los derechos fundamentales y los Tratados Internacionales sobre derechos humanos», en CASAS BAAMONDE, María Emilia y RodríguezPiñero y Bravo-Ferrer, Miguel (dirs.), Comentarios a la Constitución Española, Madrid, Fundación Wolters Kluwer, p. 201] la obligación que deriva del artículo 10.2 CE es de resultado y obliga a los intérpretes de la norma sobre derechos, en este caso al TC, a una interpretación de los mismos que no resulte contraria, por lo que a nosotros incumbe, al canon europeo. Obligación que entendemos puede estimarse cumplida en el caso del derecho a la propia imagen.

15 Por todas, Schüssel contra Austria (Decisión de 21 de febrero de 2002); von Hannover contra Alemania (STEDH de 24 de junio de 2004), y Sciacca contra Italia (STEDH de 11 de enero de 2005).

16 STC 156/2001, FJ 6 y SSTEDH 15 enero de 2009 caso Reklos y Davouris contra Grecia, § 40 y 7 febrero 2012 caso von Hannover contra Alemania (núm. 2) §96; entre otras. 
ción como la mera captación ${ }^{17}$. De lo que se sigue que toda publicación no consentida de una fotografía o documento audiovisual supone per se una afectación o, en la terminología del TEDH, una injerencia en el derecho personal a la propia imagen de la persona efigiada ${ }^{18}$. Aunque no necesariamente su vulneración, toda vez que esa misma publicación puede, asimismo, encontrar cobertura y justificación constitucional y/o convencional en cuanto ejercicio de la libertad de expresión o, en nuestro caso, de información.

Se trataría, así pues, de una interpretación constitucional del derecho que resulta convencionalmente adecuada pero que, en líneas generales y con la salvedad que se indicará más adelante, ha sido construida por el TC sin apoyo ni referencia explícita en la jurisprudencia del TEDH. Algo especialmente cierto por lo que se refiere a esta primera etapa jurisprudencial en la que la cita a la jurisprudencia de Estrasburgo en relación con esta cuestión es, prácticamente, inexistente ${ }^{19}$. Lo que, a su vez, es fácilmente explicable si tenemos en cuenta las fechas más significativas de una y otra jurisprudencia. En efecto, es preciso observar, y sobre ello volveremos más adelante, que el TC fija su doctrina sobre esta cuestión en las SSTC 139/2001 y 83/2002, por tanto unos años antes de que el TEDH dictara su sentencia más relevante — y probablemente la más conocida entre nosotros - en esta etapa sobre el derecho a la propia imagen de los perso-

17 Por todas, STC 81/2001, FJ 2. Por lo que se refiere a la jurisprudencia europea: SSTEDH de 7 de febrero de 2012 [von Hannover contra Alemania $\left(n .^{\circ} 2\right)$ ] § 96 (respecto de la divulgación) y Reklos y Davouris contra Grecia, § 41 (respecto de la mera captación). No obstante, en relación con esta última resolución, se ha señalado que en ella no queda claramente establecido cuál es el criterio del TEDH respecto de la mera captación no consentida de la imagen de una persona: si supone en todo caso una injerencia en su derecho a la vida privada o si eso solo sucedería cuando - como en el caso enjuiciado- concurran determinadas circunstancias [HugHes, Kirsty (2009), «Photographs in Public Places and Privacy», Journal of Media Law, pp. 164-165].

18 Por todas, SSTC 14/2003, FJ 6 (respecto de unas fotografías de una persona detenida en dependencias policiales y 19/2014 (personaje público); SSTEDH 13 octubre de 2015, caso Bremner contra Turquía, § 62 y 12 de diciembre de 2013, caso Khmer contra Rusia, § 40 (y la jurisprudencia allí citada).

19 Así, la encontramos tan solo en las SSTC 300/2006, FJ 2 (en relación con la reparación de la lesión que puede, en su caso, comprender una indemnización económica); 14/2003, FJ 6 (cuando señala que también el TEDH ha afirmado que la toma de una fotografía de una persona detenida constituye una injerencia en su derecho al respeto a la vida privada); y en la STC 23/2010, FJ 5 (para recordar su doctrina, destacando en este punto su sintonía con la jurisprudencia europea, conforme a la cual los denominados personajes públicos pueden ver limitados sus derechos —entre ellos la imagen - con mayor intensidad que los que las personas que no lo son, como consecuencia, justamente, de la publicidad que adquieren su figura y sus actos). 
najes públicos. Nos referimos a la Sentencia de 24 de junio de 2004, dictada en el caso von Hannover contra Alemania ${ }^{20}$.

No existe, pues, referencia jurisprudencial europea, al menos significativa, a la que nuestro TC pueda mirar en el momento de fijar su doctrina sobre el derecho a la imagen de los personajes públicos. Ello no va a impedir, sin embargo, una cierta similitud entre ambas jurisdicciones no solo respecto de los aspectos antes mencionados sino también en cuanto al modo en que la resolución de este tipo de conflictos es abordada por ambos Tribunales. Así, para el TC lo fundamental será determinar si las imágenes controvertidas van referidas a momentos de la vida privada del sujeto. O, por utilizar la terminología empleada en las SSTC 139/2001 y 83/2002, a si éstas constituyen un documento de naturaleza privada y personal que, además, ha sido obtenido de manera ilegítima y sin consentimiento del afectado $^{21}$. Por su parte, para el TEDH resulta determinante si tales imágenes contribuyen o no a un debate de interés general, sin que pueda estimarse que lo hacen cuando las mismas se refieren únicamente a momentos de la vida privada de la persona, debiendo tenerse en cuenta además las circunstancias en que han sido obtenidas, por ejemplo, sin consentimiento ni conocimiento del sujeto, en un clima de acoso mediático ${ }^{22}$.

Sin ser exactamente lo mismo, en la medida en que ambos criterios no solo no parecen incompatibles, sino que incluso podrían ser considerados equivalentes, cabe estimar esta doctrina del TC, aun en ausencia de referencia europea explícita, conforme con la que apenas unos años después habría de fijar el TEDH.

\section{EL DERECHO FUNDAMENTAL A LA PROPIA IMAGEN DE LOS PERSONAJES PÚBLICOS EN LA JURISPRUDENCIA CONSTITUCIONAL ANTERIOR A LA STC 19/2014. SU CASI NULA ASUNCIÓN POR EL TRIBUNAL SUPREMO}

Esta situación que acabamos de ver respecto de la relación de la jurisprudencia constitucional con la europea contrasta, sin embargo, con la que, también

${ }^{20}$ Calificada como leading case [CLAYTOn, Richard and Tomlinson, Hugh (eds.) (2009), The law of human rights, 2. ${ }^{a}$ ed., New York, Oxford University Press, p. 1095] o como «sin duda» «la sentencia más importante» en relación con la vida privada de los personajes públicos y, por tanto, también respecto del ámbito legítimo de ejercicio de la libertad de información respecto de los mismos [LAzCano Brotóns, Iñigo (2015), «Artículo 10. Libertad de expresión», en LasaGaBaster Herrarte, Iñaki (dir.), Convenio Europeo de Derechos Humanos. Comentario sistemático, 3. ${ }^{a}$ ed., Cizur Menor, Aranzadi, 2015, p. 605].

21 SSTC 139/2001, FJ 5 y 83/2002, FJ 4.

22 STEDH 24 de junio de 2004, caso von Hannover contra Alemania, §§ 60, 65, 68, 76. 
durante toda esta primera etapa se va a establecer, en orden al contenido y alcance del derecho a la propia imagen de los personajes públicos, con la jurisdicción ordinaria, caracterizada por la escasa sintonía que el TS va a mostrar con esta doctrina del TC. Esta disparidad, además, sin suponer un enfrentamiento abierto del TS con el TC, a diferencia de lo ocurrido en alguna ocasión a propósito del derecho a la intimidad, ni tampoco, como se verá, un apartamiento deliberado y consciente de la doctrina del TC sobre el derecho fundamental a la propia imagen, no puede, sin embargo, estimarse como algo puramente anecdótico, carente de relevancia constitucional. Antes al contrario, obedece a una causa profunda que hunde sus raíces en el sistema mismo: la diferente vinculación que uno y otro Tribunal mantienen con el legislador de los derechos fundamentales. Mientras que el Tribunal Supremo y más en general la jurisdicción ordinaria se ha mantenido, como por lo demás no podía ser de otra forma al tratarse de una norma legal cuya constitucionalidad en ningún momento ha sido cuestionada, absolutamente sujeto a lo dispuesto por el legislador en la LO 1/1982 a la hora de resolver estos conflictos, el Tribunal Constitucional, por el contrario, no se ha sentido especialmente vinculado por lo allí contenido y ha preferido conformar el canon de enjuiciamiento a partir de otros parámetros diferentes, extraídos directamente de los preceptos constitucionales en liza (arts. 18.1 CE y 20 CE) ${ }^{23}$.

Así, si hay un rasgo que define a la jurisprudencia civil del Tribunal Supremo anterior a la STC 19/2014 es lo fuertemente vinculada que se ha sentido a lo dispuesto en la LO 1/1982 a la que en líneas generales se ha atenido rigurosamente $^{24}$ y simultáneamente, como la otra cara de una misma moneda, lo escasamente penetrada que lo ha estado por esta primera doctrina del TC acerca

23 En esta misma línea, Velasco CaBAllero ha señalado cómo en «los juicios de amparo constitucional por derechos del artículo 18.1 CE (honor, intimidad, propia imagen) el Tribunal excluye del canon de enjuiciamiento la regulación de la Ley orgánica 1/1982, de 5 de mayo. En ocasiones ni se citan los preceptos de esta Ley; y en otras se citan simplemente para hacer mención al juicio realizado por los órganos judiciales, que sí aplican dicha Ley y conforme a ella declaran la vulneración —o no—- de un derecho fundamental del artículo 18.1 CE» [VELAsco CaBALLERO, Francisco (2006) «Articulación de las jurisdicciones constitucional y judicial ante lesiones de derechos fundamentales originadas por particulares», en VIVER PI-SUNYER, Carles (coord.), Jurisdicción constitucional y judicial en el recurso de amparo, Valencia, Tirant lo Blanch, p. 435]. Algo, pues, que sucede no solo en relación con la propia imagen sino también respecto del honor y la intimidad. En relación con este último derecho, se pronuncia también en el mismo sentido MiERES Mieres, Luis Javier (2011), «Nimiedades privadas ¿Tutela de un derecho o reparación de un daño? [Un comentario al caso «Isabel Preysler»]», Repertorio Aranzadi del Tribunal Constitucional, núm. 3.

${ }^{24}$ Como señala PARdo FALCón, «la LO 1/1982 ha tenido sobre todo relevancia a la hora de determinar la actuación de la jurisdicción ordinaria, particularmente en el ámbito civil.» [PARDO FALCón, Javier (2008), «Artículo 18.1. Los derechos al honor, a la intimidad personal y familiar y a la propia imagen», en CASAS BAamonde, María Emilia y Rodríguez-Piñero y Bravo- 
del modo en que deban resolverse este tipo de conflictos y más en concreto acerca del valor que quepa atribuir a las imágenes que no obstante ir referidas a personas o personajes públicos y haber sido captadas en un lugar abierto al público, por su naturaleza, contenido y modo de obtención constituyen, sin embargo, un documento de carácter privado o reservado.

Cabe recordar que el TC formula esta doctrina en sus SSTC 139/2001 y 83/2002. El supuesto de hecho en ambos casos es muy parecido: La publicación en una de las denominadas revistas del corazón ( «iez Minutos») de varias fotografías en las que se podía observar a sendos conocidos empresarios del mundo financiero (Alberto Cortina y Alberto Alcocer, respectivamente) con sus nuevas parejas sentimentales. En el primer caso las imágenes habían sido captadas en una reserva de caza en Kenia; en el segundo en una playa. En los dos, lo habían sido por su círculo más íntimo y puestas a disposición de la revista sin el consentimiento de los interesados. Y también en ambos supuestos el TS estimó el recurso de casación interpuesto por la empresa editora del semanario en el que se publicaron estos reportajes al entender que concurría la excepción prevista en el artículo 8.2.a) LO 1/1982 que excluye la ilegitimidad de la intromisión en el derecho a la propia imagen cuando se trata de la publicación de fotografías de una persona con notoriedad pública cuya imagen ha sido captada en un lugar abierto al público ${ }^{25}$.

Pues bien, el TC se aparta de esta aplicación que hace el Tribunal Supremo de lo dispuesto por el legislador y resuelve los recursos de amparo mediante la formulación de un nuevo criterio de ponderación, no contenido, ni siquiera de manera implícita, en la Ley: la naturaleza privada de las fotografías, junto a la forma ilegítima de su obtención ${ }^{26}$. O, lo que es lo mismo, si éstas vienen referidas

Ferrer, Miguel (dirs.), Comentarios a la Constitución Española, Madrid, Fundación Wolters Kluwer, p. 415].

${ }^{25}$ SSTS de 21 de octubre de 1997 y de 17 de diciembre de 1997, respectivamente. Además, en la segunda de ellas y en relación con la lesión del derecho a la intimidad alegada, estima el TS que la información publicada es de interés público («general», en palabras del TS) en la consideración de que este tipo de actos o relaciones han sido «en casos semejantes, muy semejantes, motivo para importantes cambios financieros». (STS 17 de diciembre de 1997, FJ 5).

${ }^{26}$ Precisamente ésta es una de las principales críticas que se ha hecho a esta jurisprudencia del TC — la ausencia de previsión legal— que, por lo demás, ha sido valorada en general de manera positiva. Véase, en este sentido, De la Iglesia Chamarro, Asunción (2003), «El derecho a la propia imagen de los personajes públicos. Algunas reflexiones a propósito de las SSTC 139/2001 (Caso Cortina) y 83/2002 (Caso Alcocer)», Revista Española de Derecho Constitucional, núm. 67, pp. 313-314 y Castilla Barea, Margarita (2011), Las intromisiones legítimas en el derecho a la propia imagen, Cizur Menor, Aranzadi, p. 315. 
a momentos de la vida privada del sujeto ${ }^{27}$. Se trata, además de un criterio que, caso de concurrir, desplaza no solo la aplicación de los criterios previstos legalmente sino que incluso invierte el resultado al que cabría haber llegado mediante la aplicación de éstos últimos. Es decir, si no obstante tratarse de imágenes captadas en un lugar abierto público respecto de una persona que puede se considerada pública, éstas, por su naturaleza y contenido o por las circunstancias en que fueron captadas, constituyen un documento personal de naturaleza estrictamente privada que además ha llegado al medio de comunicación «sin el consentimiento del interesado y mediante una operación de terceros ajena a su voluntad» ${ }^{28}$ ha de prevalecer la protección que el ordenamiento jurídico otorga a la propia imagen al no estar justificado en este caso la protección preferente del derecho a la información ${ }^{29}$.

Frente a esta jurisprudencia del TC, en las resoluciones de la jurisdicción ordinaria ha primado desde un primer momento, e incluso después de formulada esta doctrina constitucional, lo dispuesto de modo expreso en el artículo 8.2.a) LO 1/1982, al que jueces y tribunales no solo se han atenido rigurosamente, sino que además han interpretado de forma casi literal. De tal modo que lo único relevante resulta ser la condición de la persona a la que las imágenes se refieren (persona que ejerce un cargo público o una profesión de notoriedad o proyección pública) y el lugar en que éstas han sido tomadas (abierto al público). Una subsunción en la norma legal atemperada tan solo por una interpretación finalista de lo que sea «lugar abierto al público» que impide considerar como tal a todo aquél al que la persona pueda tener acceso en un momento determinado, sino tan solo al «que resulta de uso normal por una generalidad de personas que acceden a él fuera del ámbito estricto de su vida privada» ${ }^{30}$. E íntimamente

27 Aunque el TC no se refiere expresamente a este criterio de ponderación en estos términos («momentos de la vida privada») hasta la STC 176/2013, ambos pueden, no obstante, ser considerados equivalentes.

28 SSTC 139/2001, FJ 5 y 83/2002, FJ 4.

29 En este sentido, Pascual Medrano señala que el único criterio que permite justificar el sacrificio del derecho a la propia imagen de los personajes públicos es la concurrencia de un interés público informativo que no estaría presente en aquéllas imágenes que, aun habiendo sido captadas en un lugar abierto al público, se encuadran — como sucede con las imágenes enjuiciadas en la STC 139/2001 — en el ámbito de la vida privada de la persona. La autora adelanta así, un criterio que el TC solo acogerá expresamente — en relación específicamente con el derecho a la propia imagen - en la STC 19/2014. [Pascual Medrano, Amelia (2003), El derecho fundamental a la propia imagen. Fundamento, contenido, titularidad y limites, Cizur Menor, Thompson-Aranzadi, pp. 132 y ss.].

30 Por todas, STS 1044/2008, de 28 de noviembre, en la que se formula en estos términos por primera vez. 
relacionado con lo anterior por el criterio formulado por el TS relativo a la expectativa legítima de privacidad. De modo tal que van a quedar fuera de la consideración de lugar público, a efectos de lo dispuesto en la Ley, no solo las playas apartadas, poco concurridas o de difícil acceso ${ }^{31}$, o lugares similares como la ribera de un pantano, sino más en general, cualquier otro espacio que no cumpla con la definición anterior. Tales como las instalaciones de un hospital, incluidos pasillos y parking ${ }^{32}$; los espacios de uso común de una urbanización privada como la piscina y alrededores ${ }^{33}$; la cubierta de un yate ${ }^{34}$ o las playas nudistas ${ }^{35}$. Lugares en los que la persona sigue conservando intacta una legítima expectativa de privacidad. Y en consecuencia permanece incólume su derecho a la propia imagen —así como a la intimidad - cuya protección no cede aun cuando se trate de un personaje público, puesto que las imágenes han sido captadas en espacios que pueden seguir siendo considerados de privacidad.

Se trata, por lo demás, de un modo de resolver este tipo de conflictos, que estando ya presente en la jurisprudencia civil anterior a las SSTC 139/2001 y $83 / 2002$ apenas se va a ver alterada por la formulación que el TC hace de ese nuevo criterio de ponderación relativo a la naturaleza de las imágenes controvertidas. Si ya con ocasión de estas SSTC se hablaba de divergencia entre ambas jurisdicciones en lo que se refiere al alcance frente a los medios de comunicación del derecho a la propia imagen de estas personas que gozan de notoriedad ${ }^{36}$ esta diferencia lejos de acortarse no habría sino de mantenerse e incluso acentuarse en los años venideros. Hasta la jurisprudencia del TS posterior a la STC 19/2014.

No obstante esto, sí que han habido ocasiones en las que el TS ha hecho uso de este criterio de ponderación formulado por el TC. Un criterio al que el TS se ha referido no tanto indagando sobre la naturaleza de documento privado o no de las imágenes o de su forma de obtención como cuestionando si éstas venían referidas a momentos de la vida privada del sujeto efigiado ${ }^{37}$. Ahora bien, si en un

31 Limitación que ya adelantó el TS en su sentencia de 29 de marzo de 1998 dictada en el caso Silvia Munt.

32 STS 405/2014, de 10 de julio.

33 STS 42/2014, de 10 de febrero.

34 SSTS 674/2004, de 7 de julio; 789/2008, de 24 de julio; 499/2014, de 23 de septiembre.

35 SSTS 494/2002, de 28 de mayo; 784/2004, de 12 de julio; 1042/2004, de 25 de octubre.

36 Se trata de De la Iglesia Chamarro, Asunción (2003), op. cit., p. 287, quien lo calificaba además de «divergencia severa».

37 Seguramente influido por la propia dicción de la LO 1/1982 que en su artículo 7.5 al delimitar las conductas que tienen la consideración de intromisión ilegítima en el derecho a la propia imagen utiliza esta misma expresión («momentos de su vida privada») y probablemente, también, por la conocida doctrina del TEDH formulada en su sentencia de 24 de junio de 2004, caso von Hannover contra Alemania. 
primer momento el TS hará más bien un uso impropio del mismo, con posterioridad transformará su significado para restringir significativamente su aplicación tan solo a aquellos supuestos en los que a través de las imágenes se desvelan, no cualesquiera momentos de la vida privada del sujeto, sino tan solo aquéllos que pudieran calificarse como íntimos.

Así, en los primeros años tras las SSTC 139/2001 y 83/2002 el uso que de este criterio se hace en la jurisdicción ordinaria es más bien escaso y caracterizado porque su aplicación no lo ha sido en relación a supuestos que, a tenor de la jurisprudencia constitucional, cabría considerar su ámbito natural de aplicación. A saber, aquéllos en los que las imágenes, a pesar de haber sido tomadas en un lugar abierto al público y respecto de un personaje público, por su contenido y/o por el modo en que se han obtenido se referían a momentos de la vida privada del sujeto y, por tanto, podían ser considerados como un documento íntimo y personal, sin relevancia pública alguna. Con la consiguiente prevalencia de la propia imagen, a pesar de lo establecido en la Ley. Antes al contrario, y es por ello que se habla de un uso impropio de este criterio de ponderación, se trataba de supuestos en los que por no tratarse de un lugar abierto al público no resultaba de aplicación la excepción contenida en el artículo 8.2 a) LO 1/1982 ${ }^{38}$. La utilización del criterio sirve así tan solo para corroborar la conclusión alcanzada a partir de la propia Ley y sin que en modo alguno actúe como dirimente del conflicto suscitado, a diferencia de lo sucedido en los casos enjuiciados por el TC y que dieron lugar a su formulación.

Habrá que esperar a finales de esta primera década del presente siglo para que el TS aplique de manera más habitual el criterio que nos ocupa. Pero este mayor uso, ahora sí referido a casos en lo que resulta de aplicación la excepción del artículo 8.2.a) LO 1/1982, irá acompañado de una significativa reducción de su significado y ámbito de aplicación de tal modo que lo será, no cuando se trate de cualquier situación referida a la vida privada del sujeto, en general, sino tan solo cuando se trate de lo que el TS ha calificado como «momentos íntimos

38 Es el caso de las SSTS 705/2002, de 12 de julio y 789/2008, de 24 de julio. En ambas el TS excluye que sea de aplicación la excepción prevista en el artículo 8.2.a) LO 1/1982, ya que las imágenes fueron tomadas en lugares que no tenían la consideración de públicos. Más concretamente, en ambas lo fue en el interior de sendas fincas privadas utilizando medios capaces de captar imágenes a distancia, desde el exterior y referidas, a momentos de la vida desarrollada en estos lugares y, por tanto, privada. Junto a éstas también se refiere el TS a este criterio en la STS 1050/2008, de 18 de noviembre, pero precisamente para excluir que las fotografías —en «top less» de una modelo española de fama internacional en una playa de Jamaica de libre acceso y, por tanto, en un lugar abierto al público — tuvieran carácter estrictamente privado o familiar. 
de su vida privada» ${ }^{39}$. Sólo en estos casos decaerá la aplicación del artículo 8.2.a) LO 1/1982 y por consiguiente primará, de acuerdo con esta doctrina del TS, la protección de la propia imagen.

Pero se trata de una restricción que, además de reducir de manera injustificada el ámbito de aplicación de este criterio, denota la confusión existente en la jurisprudencia ordinaria entre lo que sea el derecho a la imagen y el ámbito susceptible de protección a través del derecho a la intimidad, hasta el punto de hacerlos coincidir. Al menos, cuando se trate de la imagen de personas públicas captadas en lugares públicos. Sin entrar ahora en la distinción entre «vida privada» e «intimidad», lo que por otra parte excede el propósito de este trabajo, lo cierto es que no solo no parece que fuese ésta la intención del TC cuando formuló este nuevo criterio de ponderación, limitarlo a los casos en los que a través de la imagen se afecta también el ámbito propio de la intimidad ${ }^{40}$, sino que tampoco resulta coherente con la misma definición constitucional del derecho a la propia imagen. Cuyo ámbito específico de protección viene referido a aquellas reproducciones no consentidas de la imagen física «que, afectando a la esfera personal de su titular, no lesionan su buen nombre ni dan a conocer su vida íntima, pretendiendo la salvaguarda de un ámbito propio y reservado, aunque no intimo, frente a la acción y conocimiento de los demás» ${ }^{41}$.

Otro tanto cabe decir por lo que se refiere a la doctrina del TEDH. No solo porque la noción de vida privada contenida en el $\mathrm{CEDH}$ es, en general, más amplia que la de intimidad a que se refiere nuestro artículo 18.1 CE, sino porque específicamente, por lo que se refiere al conflicto con la libertad de expresión, el TEDH ha estimado dignas de protección imágenes que mostraban a la persona en escenas de su vida cotidiana, en actividades - como haciendo deporte, paseando, saliendo de un restaurante o de vacaciones - que pudiéramos estimar privadas, pero no íntimas ${ }^{42}$.

39 Por todas, SSTS 1050/2008, de 18 de noviembre, FJ 2; cursiva añadida.

40 Antes el contrario se observa en la jurisprudencia del TC un entendimiento mucho más amplio de cuándo las imágenes controvertidas, por su naturaleza, constituyen un documento estrictamente privado y personal. Así, en la STC en la que se formula este criterio y tras constatar la naturaleza privada de las fotografías en cuestión se afirma que «No es preciso examinar si tal documento se halla en el ámbito propio de la intimidad, puesto que ni en la demanda de amparo se invoca expresamente el derecho a la intimidad ni, por otra parte, se condicionan mutuamente, de modo necesario, este derecho y el de la propia imagen, dada la autonomía de uno y otro (...) es, en todo caso, claro - y suficiente a los fines del presente proceso- que dichas imágenes se insertan en el ámbito propio y reservado de lo que es la esfera personal de los afectados» (STC 139/2001, FJ 5).

41 STC 81/2001, FJ 2; cursiva añadida.

42 STEDH de 24 junio de 2004, caso von Hannover contra Alemania. 
En cualquier caso, y desde luego apartándose del entendimiento más amplio que de este criterio cabe apreciar tanto en el TC como en el TEDH, lo cierto es que, allí donde el TS hace uso del mismo lo va a hacer bajo el escrutinio mucho más estricto de si las imágenes (de un personaje público en un lugar público) desvelan aspectos de la vida íntima del sujeto. Entendiendo que concurre tal circunstancia cuando se trata de las relaciones afectivas, sentimentales o sexuales de la persona o cuando las fotografías muestran su cuerpo desnudo o semidesnudo. Aspectos que, por lo demás, entrarían dentro del ámbito de protección del derecho a la intimidad, en general o en su modalidad de intimidad corporal. Salvo que la propia persona haya consentido expresamente no solo la captación sino también la publicación de tales imágenes o que con su propia conducta y pautas de comportamiento haya hecho descender las barreras propias del derecho a la intimidad ${ }^{43}$. Allí donde en efecto y a juicio del tribunal, las imágenes han servido de instrumento para revelar aspectos relativos a la vida íntima del sujeto, se estima lesionado indistintamente o solo el derecho a la intimidad o de éste conjuntamente con la imagen.

Pero, por el contrario, en todos aquellos otros en los que se estima que la imagen no desvela ningún momento de la vida íntima del sujeto se descarta, no solo la posible lesión del derecho a la intimidad, caso de haber sido alegada, sino también del derecho a la propia imagen ${ }^{44}$. A no ser que, o no concurran las circunstancias contenidas en la Ley para la exclusión de la protección de este último derecho, por ejemplo, porque no se trata de un lugar abierto al público en el sentido en que esta noción ha sido interpretada por el TS, o que el sujeto haya buscado expresamente el apartamiento físico en un intento por preservar su imagen y su privacidad. Con el resultado de que los personajes públicos quedan prácticamente desprovistos de su derecho a la imagen en los lugares abiertos al público y solo lo conservan cuando se trata de lugares y espacios privados o de privacidad $^{45}$.

${ }_{43}$ Porque, por ejemplo, se ha expuesto a la mirada ajena sin la parte superior del bikini en una playa pública (STS 435/2011, FJ 3) o porque los interesados se profesan gestos de afecto en lugares públicos sin adoptar medidas para sustraerse a la curiosidad ajena (STS 270/2012). Entiende el TS que en estos casos los sujetos quedan desprovistos de la protección que otorga la intimidad.

${ }_{44}$ Es lo que sucede, por ejemplo, en las SSTS 400/2009, FJ 3; 878/2010, FJ 5; 281/2011, FJ 4. En todas ellas se trata de imágenes que muestran al sujeto en momentos de su vida privada, cotidiana, pero no íntima.

45 Así, el propio TS ha afirmado de modo expreso que «en las personas o actividades de proyección y trascendencia pública la protección del derecho al honor disminuye, la de la intimidad se diluye y la de la imagen se excluye» (cursiva añadida). Precisamente porque se entiende que así lo dispone la propia LO 1/1982, en su artículo 8.2.a). El TS se refiere a ello por primera vez, en 
De este modo, sin rechazar expresamente el criterio de ponderación formulado por el TC ni, por tanto, la doctrina constitucional acerca del alcance del derecho a la propia imagen de este tipo de personas frente a los medios de comunicación ni sobre el modo en que deban resolverse este tipo de conflictos, se excluye por el TS su aplicabilidad, en la inmensa mayoría de las ocasiones, al caso concreto enjuiciado.

No obstante, al mismo tiempo que el TS trata de resolver estos conflictos principalmente a través de la aplicación de los criterios contenidos en la LO 1/1982 empieza a hacer aparición en el discurso del TS, de un modo cada vez más frecuente, la alusión al interés público de la información. Al que también denomina en ocasiones interés informativo o, simplemente, interés gene$\mathrm{ral}^{46}$. No obstante, es posible apreciar también aquí una evolución en el sentido y alcance que el TS atribuye a esta noción y que como tendremos ocasión de comprobar inmediatamente condiciona de manera extraordinaria la protección efectiva que va a acabar recibiendo la propia imagen en la jurisdicción ordinaria.

Así en las resoluciones dictadas en los primeros años del presente siglo es posible apreciar que el TS maneja una noción estricta de lo que sea interés público informativo descartando que concurra en aquellas informaciones cuya finalidad es meramente satisfacer la curiosidad del público por conocer la vida de otros, propio de las denominadas revistas del corazón o prensa rosa o, como la denominará el propio TS, del entretenimiento. $\mathrm{O}$ en las que solo está presente un interés crematístico, publicitario o comercial, pero no propiamente informativo. En este sentido se pronuncian por ejemplo las SSTS 623/2004, de 1 de julio y 789/2008, de 24 de julio ${ }^{47}$. Curiosamente, tan solo unos meses después de esta última se va a producir un giro en esta jurisprudencia de tal modo que ya en la STS 1050/2008, de 18 de noviembre, se acoge una noción amplia de lo que sea interés informativo digno de protección constitucional al señalar que la información protegible no necesariamente tiene que ser política, económica, científica o cultural, en definitiva lo que entendemos por interés público en sentido estricto, «sino que también existe el género más frívolo de la información de

relación con la imagen, en su STS de 17 de diciembre de 1997 y desde entonces se ha ido reproduciendo de manera más o menos periódica. Así, lo encontramos, entre otras en las SSTS 117/2000, FJ 3; 323/2010, FJ 2; 432/2000, FJ 2; 7/2009, FJ 3; 408/2014, FJ 2.

46 Por todas, SSTS 388/2009, de 9 de junio y 1021/2004, de 18 de octubre, respectivamente.

47 «(...) esta Sala no viene considerando de interés general o relevancia pública lo que no tiene interés histórico, científico o cultural relevante, sino que solo satisface la curiosidad humana por conocer la vida de otros, o ánimo de lucro por quien obtiene o difunde la información» (STS 789/2008, FJ 2). 
espectáculo o de entretenimiento» ${ }^{48}$. Se trata, además, un cambio de tendencia que no hará sino consolidarse en cada nueva ocasión que tenga el TS de pronunciarse sobre esta cuestión ${ }^{49}$. Otorga, así, el TS, cobertura a lo que de una manera bastante expresiva se ha denominado «info-entretenimiento» ${ }^{50}$. De este modo, el interés público informativo pasa a estar presente no solo en aquellas informaciones que abordan temas políticos, económicos, científicos o culturales, sino más en general en todas aquellas «que, cualquiera que sea su objeto o formato, sean susceptibles de influir sobre la opinión pública» ${ }^{51}$.

Ahora bien, esto no implica necesariamente, que el TS otorgue en todo caso una protección preferente a este tipo de informaciones o imágenes frente al derecho personal afectado. Pero sí que no se descarta de plano que las mismas gocen de relevancia pública y por tanto merezcan ser protegidas incluso contra la voluntad del sujeto cuyo derecho personal resulta afectado por la publicación de las mismas. Admitido esto, lo normal es que los propios Tribunales ordinarios reconozcan a este tipo de informaciones, propias de la crónica social o del entretenimiento, en definitiva, del espectáculo mediático, un interés público escaso. No en vano se trata de programas e informaciones que, como el TS ha reconocido, no tienen por objeto contribuir al debate público en una democracia sino únicamente satisfacer la curiosidad ajena por conocer detalles de la vida privada de las personas que gozan de cierta notoriedad pública ${ }^{52}$.

Pero admitido esto, lo cierto es que el TS ha tendido a valorar de manera diferente las imágenes enjuiciadas, por lo que al interés público presente en las mismas se refiere, según que a través de las mismas se afecte únicamente al derecho a la propia imagen o sirvan también como vehículo para la lesión del derecho

${ }^{48}$ STS $1050 / 2008$, FJ 3.

49 No obstante, todavía en la STS 1100/2008, de 13 de noviembre, se descarta que concurra un interés público digno de protección constitucional en aquellas informaciones que, como ocurre en el caso allí enjuiciado, están dirigidas a «satisfacer solo la curiosidad morbosa en torno a la esfera íntima, sexual, de la afectada» (FJ 3).

${ }^{50}$ La expresión corresponde a RoDRíGuEZ, Ángel (2016), op. cit., p. 449, quien la utiliza para designar a aquellos mensajes, normalmente típicos de determinados medios (la prensa «rosa»o «del corazón») o programas (los dedicados al cotilleo, conocidos como «telebasura») que toma la justicia como un espectáculo mediático. Más allá del ámbito judicial en el que la utiliza el autor (info-entretenimiento judicial) entendemos que la noción es plenamente aplicable al supuesto que nos ocupa en el que el espectáculo mediático — y el beneficio económico a él asociado — se nutre de proporcionar a los lectores de este tipo de medios o a la audiencia de este tipo de programas detalles — normalmente en forma de imágenes — sobre la vida privada de determinado tipo de personas (con notoriedad pública, «famosos»).

${ }^{51}$ STS 719/2009, de 16 de noviembre, FJ 10; reiterado en numerosas resoluciones posteriores, entre otras, STS 878/2010, FJ 5; 442/2010, FJ 4; 471/2011, FJ 4.

52 Por todas, STS 90/2011, FJ 4. 
a la intimidad de los sujetos implicados. Es precisamente en este último supuesto que el TS viene considerando insuficiente el interés público presente en estas informaciones propias del mero entretenimiento mediático. Insuficiente, en todo caso, para que pueda entenderse justificada la divulgación de datos relativos a la intimidad del sujeto, con la consiguiente lesión de este último derecho ${ }^{53}$.

Muy diferente, sin embargo, es la consideración que este tipo de informaciones o imágenes merecen en la jurisprudencia del TS cuando se trata únicamente del derecho a la propia imagen. Cuando este es el único derecho afectado, y siempre que concurran las condiciones establecidas en la Ley para la aplicación de la excepción a que se refiere el artículo 8.2.a) LO 1/1982, el escaso interés público presente en la denominada prensa del entretenimiento resulta ser suficiente para entender justificada la publicación de tales imágenes. En estos casos, y más allá de que lo determinante sigue siendo la concurrencia de los elementos personales y espaciales a que se refiere expresamente el artículo 8.2.a) LO 1/1982, el TS viene - o ha venido hasta fecha muy reciente como se indicará a continuación- otorgando plena cobertura constitucional a este tipo de informaciones propias de la crónica social o del mero entretenimiento mediático al entender que también concurre aquí un interés público — «el propio de los medios pertenecientes al género del entretenimiento», según el TS— susceptible de justificar la intromisión en el derecho a la imagen del personaje público que se ve así obligado a soportar la captación y difusión no consentida de las imágenes relativas a su persona ${ }^{54}$.

De este modo, el uso del interés público informativo lejos de erigirse en criterio determinante de la ponderación jurisprudencial que sirva para matizar

53 Así cuando se trata de este tipo de informaciones entiende el TS que el grado de afectación de la libertad de información es débil. Precisamente porque también lo es el interés público presente en este tipo de informaciones dado que su finalidad es de mero esparcimiento y no la de contribuir a la formación de la opinión pública (STS 525/2011, FJ 4). Por el contrario, y dado que a través de ellas se divulgan aspectos que se encuadran en un ámbito propio y reservado del sujeto, sin que medie consentimiento, se entiende que el grado de afectación del derecho a la intimidad, frente a la protección de la libertad de información, es muy elevado. (STC 284/2011, FJ 7).

54 Especialmente gráfica resulta a este respecto el siguiente pasaje extraído de la STS 125/2011: «La información publicada tenía interés público, que es el interés propio de los medios pertenecientes al género de entretenimiento, plenamente admitido por los usos sociales, para el que puede ser noticia el físico de una reconocida actriz o su top-less. Las imágenes fueron captadas en un sitio público, como es una playa pública normalmente concurrida, por lo que su obtención ha de calificarse de lícita. Son además reflejo de un comportamiento admitido por los usos sociales. La ilicitud o ilicitud en la captación no puede depender del tipo de prendas que se utiliza: si el personaje es público, y se encuentra en un lugar público, ha de saber que su imagen en actos no privados puede ser captada de la misma forma en la que se muestra, cuando no se ha buscado el apartamiento del lugar para preservarla.» (FJ 4; cursiva añadida). 
la interpretación y aplicación de la previsión legal actúa justamente para corroborar el resultado alcanzado mediante la aplicación de los criterios legales y, en consecuencia, para confirmar el sacrificio de la propia imagen. No solo la publicación de estas imágenes estaría justificada legalmente sino que, además, desde el punto de vista del derecho de la información, concurriría el interés público necesario para considerar prevalente este último derecho. Aun cuando se trate de uno tan espurio y tan alejado de la noción primigenia relacionada con la contribución de tales informaciones a un debate de interés general o, lo que es lo mismo, a la formación de una opinión pública libre, como es el que está presente en los medios dedicados al info-entretenimiento.

\section{EL DERECHO FUNDAMENTAL A LA PROPIA IMAGEN DE LOS PERSONAJES PÚBLICOS EN LA ÚLTIMA JURISPRUDENCIA DEL TRIBUNAL CONSTITUCIONAL. SU - AHORA SÍ- RECEPCIÓN POR EL TRIBUNAL SUPREMO}

Esta jurisprudencia ordinaria a la que acabamos de hacer referencia será corregida - a nuestro juicio de manera acertada - por el TC, en varios sentidos. En un primer momento, mediante la STC 176/2013 y de modo contundente, por lo que específicamente al derecho a la propia imagen se refiere, en la STC 19/2014 ${ }^{55}$. Así, en la primera de ellas, el TC volverá a reiterar, más de una década después de su formulación inicial, que el elemento determinante para resolver este tipo de conflictos es justamente la naturaleza de las imágenes controvertidas $^{56}$. Al tiempo que vuelve a poner en valor la forma en que las mismas han sido obtenidas. Si para el TS la circunstancia de que unas imágenes hubieran sido tomadas a distancia y con teleobjetivo no permite calificarlas como clandestinas u obtenidas subrepticiamente siempre que lo hubieran sido en un lugar abierto al público y respecto de una persona con notoriedad que no había toma-

55 Destaca la influencia de estas SSTC en la «nueva y creciente sensibilidad» de los Tribunales ordinarios españoles, incluido el TS, tendente a una protección más enérgica del derecho a la propia imagen así como de los restantes de la personalidad (honor e intimidad), DE VERDA Y BEAMONTE, José Ramón (2015), «Los derechos al honor, a la intimidad y a la propia imagen como límites del ejercicio de los derechos fundamentales de información y expresión: ¿una nueva sensibilidad de los Tribunales?», Derecho Privado y Constitución, núm. 29, pp. 424 y ss.

56 STC 176/2013, FJ 6. 
do las suficientes precauciones para preservar su privacidad ${ }^{57}$, ahora el TC va a rechazar de modo rotundo esta forma de razonar ${ }^{58}$.

De modo que si — cualesquiera que sean las personas que en ellas aparecen y el lugar en que fueron tomadas, es decir, con independencia de lo establecido en el artículo 8.2.a) LO 1/1982 - por su naturaleza y las circunstancias que rodearon su captación (clandestinamente, a distancia y con teleobjetivo) y/o divulgación (mediante una operación de terceros ajena a la voluntad del sujeto) las imágenes constituyen un documento de carácter personal y privado entonces su publicación no está amparada por el derecho a la información. Constituyendo, por tanto, una vulneración del derecho a la propia imagen.

Además, recuerda el TC que la noción de interés público constitucionalmente protegido al amparo de la libertad de información es siempre una noción estricta que no se identifica con el carácter meramente noticioso de cualquier información ni con el interés presente en algunos medios por satisfacer la curiosidad humana por conocer la vida de otros. Antes al contrario, solo cabe hablar de interés público digno de protección constitucional respecto de aquellas informaciones que son relevantes para la comunidad, susceptibles de afectar al conjunto de los ciudadanos o a la vida política del país. Interés que no concurre cuando, como en el caso analizado en esta sentencia, se trata, por ejemplo, de divulgar las relaciones afectivas de los fotografiados ${ }^{59}$.

57 SSTS 611/2009, FJ 2; 719/2009, FJ 10; 878/2010; FJ 5; 125/2011, FJ 4; 425/2011, FJ $11 ; 525 / 2011$, FJ 4; 458/2011, FJ 8; 909/2011, FJ 5; 270/2012, FJ 5; 561/2013, FJ 3. Precisamente el que las imágenes de una persona famosa tomadas a distancia y con teleobjetivo no lo fueran en un lugar público, sino privado (interior de un restaurante en el que se celebraba una fiesta privada) fue lo que llevó al TS a considerar en su STS 756/2010, FJ 4 que en este caso sí se trataba de fotografías «obtenidas clandestinamente o de manera furtiva».

58 «A tal efecto es irrelevante el solo dato de que las imágenes fueran captadas en las dependencias de un establecimiento hotelero, pues ello no elimina la relevante circunstancia de que aquéllas fueron obtenidas clandestinamente por un reportero profesional de los especializados en este tipo de captación de imágenes (paparazzi), y sin que los recurrentes abrieran su ámbito reservado al público conocimiento». (STC 176/2013, FJ 7). En el mismo sentido se pronuncia también la STC 7/2014, FJ 4.

59 «En el presente caso la revelación de las relaciones afectivas de los recurrentes carece en absoluto de cualquier trascendencia para la comunidad, porque no afecta al conjunto de los ciudadanos ni a la vida política del país, al margen de la mera curiosidad generada por la propia cadena de televisión al atribuir un valor noticioso a la difusión de las repetidas imágenes, lo que no debe ser confundido con un interés público digno de protección constitucional» (STC 176/2013, FJ 7). Afirmación relativa a la nula relevancia pública de las informaciones relativas a las relaciones afectivas de las personas que el TC ya había efectuado con anterioridad (STC 83/2002) y que volverá a reiterar con posterioridad (SSTC 7/2014; 19/2014; 18/2015) constituyendo así un clásico en la jurisprudencia constitucional. 
Pero con todo el verdadero punto de inflexión habría de producirse con la STC 19/2014. Una sentencia que no solo va a tener un impacto decisivo en el modo en que este tipo de conflictos entre las libertades informativas y el derecho a la propia imagen venía siendo resuelto por el TC al sustituir el criterio hasta entonces empleado por otro, sino que también va a marcar un antes y un después en la forma en la que el Tribunal Supremo se venía relacionando con la jurisprudencia del TC sobre esta cuestión.

Así, por lo que se refiere a la evolución en la propia doctrina del TC sobre este derecho, esta sentencia no solo va a reiterar el carácter estricto de lo que sea interés público informativo, sino que además en ella el TC va a erigir a éste en el criterio decisivo, determinante, para la resolución de aquellos conflictos que pudieran plantearse entre las libertades de expresión e información y el derecho a la propia imagen ${ }^{60}$. Modifica así de manera sensible el TC la manera en que hasta entonces había abordado la resolución de este tipo de controversias, desplazando al criterio hasta entonces empleado, relativo - como hemos visto- a la naturaleza privada de las imágenes y su forma (ilegítima) de obtención por otro, consistente en el carácter noticiable de la imagen controvertida, esto es, si es, o no, de interés público. O lo que es lo mismo, si posee la relevancia pública requerida para que deba prevalecer su publicación al amparo de la libertad de información. Entendiendo que concurre tal condición respecto de aquellas imágenes que contribuyen a un debate de interés general, a la formación de la opinión pública.

${ }^{60}$ Un análisis crítico de esta STC 19/2014, a partir de consideraciones diferentes, lo encontramos en De Verda y Beamonte y en Bustos Gisbert. El primero de ellos reprocha al TC que base toda su argumentación en la ausencia de un interés público a la información que justifique la intromisión en el derecho a la propia imagen, sin hacer mención alguna al artículo 2.1 LO 1/1982 (tradicionalmente empleado por la jurisdicción ordinaria para la resolución de este tipo de conflictos relativos a la publicación de imágenes en top less de personas famosas en playas públicas) ni, por tanto, al alcance que deba dársele al mismo para la resolución de este tipo de problemas [De Verda y BeAmonte, José Ramón (2015), ibídem, pp. 432-436]. El segundo, por su parte, no comparte la noción de interés público que maneja el TC en esta sentencia a la que reprocha, entre otras cosas, que excluya taxativamente que los medios del entretenimiento contribuyan a la formación de una opinión pública libre. «Ciertamente no contribuyen de la misma forma que los medios serios, pero eso no significa que no lo hagan en absoluto, a no ser que adoptemos una interpretación de lo que sea una opinión pública libre absolutamente restrictiva.» [Bustos GisberT, Rafael (2016), «Vida privada y derecho a la información. Desarrollos jurisprudenciales en 2013-2014: la extraña y tardía recepción de Carolina en España», Revista Española de Derecho Constitucional, núm. 107, p. 398]. 
En palabras del TC;

«El carácter noticiable de la información se erige, por tanto, en el "criterio fundamental" (STC 197/1991, de 17 de octubre, FJ 2) y "decisivo" (STC 176/2013, FJ 7) que hará ceder un derecho público subjetivo como el derecho a la imagen que se funda en valores como la dignidad humana. El derecho a la información no ocupa una posición prevalente respecto del derecho a la imagen, solo se antepone a este último tras apreciar el interés social de la información publicada como fin constitucionalmente legítimo. La intromisión en el derecho a la imagen de terceros, resultante del ejercicio de la libertad de información, solo será legítima en la medida en que la afectación de dichos derechos resulte adecuada, necesaria y proporcionada para la realización constitucional del derecho a la libertad de información (STC 12/2012, de 30 de enero, FJ 6), la cual tiene como finalidad que "el ciudadano pueda formar libremente sus opiniones y participar de modo responsable en los asuntos públicos" (STC 159/1986, de 16 de diciembre, FJ 6)» (STC 19/2014, FJ 6).

Al razonar de este modo no solo se alinea nuestro TC con la jurisprudencia europea en cuanto al papel determinante que en orden a la resolución de este tipo de conflictos le corresponde desempeñar al interés público de las imágenes controvertidas, sino que además supone también la aplicación por vez primera a la propia imagen del mismo tratamiento jurídico que ya venía nuestra jurisdicción constitucional dispensando a los derechos a la intimidad y al honor cuando estos entraban en conflicto con las libertades de expresión e información. Con lo que constatada su veracidad — lo que en el caso de la imagen se presupone, salvo manipulación - la resolución del mismo dependerá en todo caso de si la información o, por lo que aquí interesa especialmente, la imagen en cuestión es o no de interés público.

Pues bien, exceptuados aquellos supuestos en los que las imágenes sobre personajes públicos los muestren en relación con unos hechos que por sí mismos son de interés público, solo cabrá apreciar que concurre tal relevancia cuando la imagen en cuestión o el documento audiovisual de que se trate «versen sobre aspectos conectados a la proyección pública de la persona a la que se refiere» ${ }^{61}$. Se pasa así de excluir de la protección que otorga el derecho a la información la difusión de aquéllas imágenes que por su naturaleza y circunstancias puedan ser consideradas como un documento personal y privado, o lo que es lo mismo, a las que muestran al personaje público en momentos de su vida privada, a estimar que tal publicación solo encuentra cobertura constitucional cuando se trate de imágenes noticiables, esto es, de interés o relevancia pública. Lo que supone una

${ }^{61}$ SSTC 12/2012, FJ 6 y 19/2014, FJ 7; entre otras. 
significativa ampliación del ámbito de protección que respecto de este tipo de personas otorga el derecho fundamental a la propia imagen. No ya respecto de lo previsto por la LO 1/982 en el modo en que venía siendo interpretada por la jurisdicción ordinaria, sino incluso respecto de la propia jurisprudencia precedente del TC sobre esta cuestión. Se pasa así de estimar que solo están efectiva y finalmente protegidas frente a su difusión mediática aquellas imágenes sobre personas públicas que puedan ser consideradas un documento personal y privado, entre otras circunstancias por mostrarlos en momentos de su vida privada, a afirmarse que solo está constitucionalmente justificada dicha publicación cuando la imagen en cuestión sea de interés público.

Pero esta sentencia no solo supone una evolución significativa en la propia jurisprudencia del TC sobre esta cuestión, sino que también va a tener un impacto relevante en la jurisprudencia del TS y, por ende, en el modo en que ésta se venía relacionando con la doctrina del TC. Si hasta entonces la relación entre ambos Tribunales, en cuanto al derecho a la propia imagen de los personajes públicos y su capacidad para actuar como límite eficaz al ejercicio de las libertades informativas, se había caracterizado por una profunda divergencia será ahora, con ocasión de esta sentencia del TC, cuando esta empiece a acortarse. Y lo hará en la medida en que el TS recepciona la doctrina del TC en los dos aspectos clave que habían marcado dicha discrepancia. De una parte, la determinación del canon de enjuiciamiento o, lo que es lo mismo, la fijación de los criterios conforme a los cuales habrá de resolverse este tipo de conflicto. Aunque el TS - a diferencia del TC pero de modo semejante a lo que sucede en la jurisprudencia del TEDH — va a seguir haciéndolo mediante la técnica de la ponderación entre derechos en la que integra ahora, como un elemento decisivo del resultado, la relevancia o interés público de las imágenes controvertidas. De otra, el modo (estricto, riguroso) en que ha de entenderse qué sea interés público informativo y, sobre todo, cuándo cabe apreciar que concurre, respecto de qué tipo de informaciones.

Así con respecto a la última de estas cuestiones y en contraste con la noción excesivamente laxa, que hasta poco antes de dictarse de la STC 19/2014 se sostenía en la jurisprudencia del TS $^{62}$ es posible apreciar ahora un entendimiento más estricto, acorde con el establecido por el TC, de lo que sea interés público informativo. De tal modo que sin llegar a excluir de modo tajante que pueda estar también presente en los denominados programas del corazón o del entre-

${ }^{62}$ La STS 11/2014, de 22 de enero es una buena muestra de ello. 
tenimiento sí que se reconoce, en líneas generales ${ }^{63}$, que este tipo de informaciones no contribuyen, sin embargo, a la formación de una opinión pública o a un debate de interés general, sino tan solo a satisfacer la mera curiosidad humana por conocer determinados aspectos de la vida e incluso del físico de otras personas. Pero mientras que con anterioridad este escaso interés público presente en este tipo de informaciones o programas solía estimarse suficiente para otorgar cobertura a la publicación de las imágenes en cuestión, ahora se entiende que esto solo ocurrirá cuando las mismas vengan referidas, si no a un acontecimiento de interés general, sí a algún aspecto de la actividad profesional o similar a la que dicha persona debe su notoriedad o proyección pública ${ }^{64}$. Lo que, dicho sea de paso, no suele ser lo habitual en este tipo de informaciones por lo que habrá que suponer que en la mayoría de las ocasiones prevalecerá la protección de la propia imagen frente a su difusión mediática. Se evidencia así cómo la doctrina del TC ha permeado la jurisprudencia del TS que ha acabado por hacerla suya también.

Pero es que además esta noción — la del interés público informativo- pasa a ocupar, también en la jurisprudencia del TS y no solo en la del TC, el lugar central en el juicio conforme al cual habrá de determinarse la legitimidad o no de la publicación no consentida de tales imágenes. Es lo que sucede, por ejemplo, en las SSTS 405/2014, 499/2014, 498/2015, 573/2015, 471/2016 y 538/2016. Aunque también es cierto que incluso una vez descartado todo interés público relevante en las imágenes publicadas, no siempre renuncia el TS a analizar el asunto también bajo la lupa de lo dispuesto en el artículo 8.2. a) LO 1/1982 y de la excepción allí contenida. La STS 471/2016 constituye un supuesto singular en este sentido al no contener, a diferencia de las otras citadas, referencia

63 Decimos en líneas generales por cuanto es posible encontrar excepciones a esta línea jurisprudencial. Así en la STS 269/2015, FJ 3 encontramos la siguiente afirmación, más acorde con la doctrina previa del TS sobre esta cuestión: «Del mismo modo ha señalado esta Sala (sentencias núm. 400/2009, de 12 junio, y núm. 24/2015, de 29 enero, entre otras) que no puede exigirse que todas las informaciones versen sobre asuntos políticos, económicos, científicos o culturales ni que cumplan siempre la función de generar debates trascendentes en una sociedad democrática. La jurisprudencia reconoce que, efectivamente, existen programas de entretenimiento encaminados a satisfacer la curiosidad ajena, sin que esta circunstancia sea suficiente para descartar en abstracto una eventual posición prevalente de la libertad de información, pese a la negativa valoración que pudieran merecer, como ocurre con las noticias referidas a personas que participan en los mismos.». Lo mismo sucede en el caso de la STS 258/2016, de 19 de abril, FJ 2 in fine en la que se vuelve a confundir el interés público propio del ejercicio de la libertad de información con el interés de cierto tipo de lectores, los de la llamada prensa rosa o del corazón, por conocer los detalles sobre la vida amorosa de determinados personajes públicos.

64 Por todas, STS 499/2014 con abundante cita, a su vez, de la STC 19/2014. 
alguna en su argumentación, siquiera sea para descartarlo, a la condición de personaje público ni a si se trataba o no de un lugar abierto al público ${ }^{65}$. No obstante, en las demás resoluciones mencionadas, este uso que se ha hecho de la Ley —el art. 8.2.a) LO 1/1982 — ha sido coincidente con el resultado alcanzado a partir de la indagación relativa a si las imágenes presentan o no un interés público informativo que justifique su publicación. Así, descartado que concurran las circunstancias allí previstas, bien porque el lugar en que las imágenes fueron captadas no era público o porque la persona no encajaba en la condición de personaje público, se excluye asimismo que las imágenes presenten interés público informativo alguno que justifique su divulgación ${ }^{66}$.

\section{LA RELACIÓN DE LA JURISPRUDENCIA CONSTITUCIONAL CON LA DEL TRIBUNAL EUROPEO DE DERECHOS HUMANOS SOBRE ESTE DERECHO VISTA A TRAVÉS DE LA STC 19/2014}

Finalmente queremos detener nuestra atención en otra cuestión por la que esta sentencia de nuestro Alto Tribunal presenta un interés adicional: a través de ella es posible observar la relación que, en esta segunda etapa, se establece entra la jurisprudencia del TC y la del TEDH respecto del modo en que haya de resolverse el conflicto entre las libertades de expresión e información y el derecho fundamental a la propia imagen de los personajes públicos. Señalábamos antes cómo, a pesar de que el TC formula su primera doctrina sobre esta cuestión antes de que el TEDH dicte su sentencia más emblemática al respecto, era posible

65 Además, realiza aquí el TS no solo una exposición detallada de cuál es la jurisprudencia del TC al respecto, sino que incluso resuelve el caso concreto aplicando dicha doctrina del TC en detrimento de su propia jurisprudencia, cuya aplicación habría dado lugar a un resultado ciertamente diferente.

${ }^{66}$ Es lo que sucede en las SSTS 405/2014, 499/2014 y 538/2016. Referidas ambas a personajes públicos. En ellas, además de descartar que las imágenes fueran tomadas en un lugar abierto al público se destaca el escaso o nulo valor informativo presente en las mismas, lo que inclina el juicio de ponderación a favor del derecho a la propia imagen. Lo mismo sucede en el caso enjuiciado en la STS 573/2015. Aunque en este caso lo determinante sigue siendo el nulo interés informativo presente en las fotografías controvertidas que se limitan a mostrar a su protagonista en momentos de su vida privada, el TS rechaza, además, que concurra en ella la condición de personaje público por haber adquirido, como sostenía el medio de comunicación, una «relevancia pública sobrevenida» a raíz de verse involucrada en unos hechos que son objeto de investigación penal. Un razonamiento parecido encontramos en la STS 547/2016 en la que el TS no solo destaca que, en el momento de publicarse las imágenes, la persona protagonista de las mismas hacía ya tiempo que no podía considerarse como un personaje público, sino también la especial intensidad gráfica de las fotografías que la muestran postrada en una silla de ruedas. 
apreciar una sustancial sintonía entre ambas. Es justamente después, existiendo ya esta resolución cuando se va a producir un cierto desacoplamiento de nuestra jurisprudencia constitucional con la del Tribunal de Estrasburgo. De una parte, porque habrá que esperar casi una década para que nuestro TC cite expresamente la STEDH dictada en 2004 en el caso von Hannover contra Alemania ${ }^{67}$. Así, no será hasta la STC 12/2012 y, específicamente en relación con el derecho a la imagen de las personas públicas hasta la STC 19/2014, que el TC va a invocar por vez primera esta sentencia europea. De otra, porque esta recepción va a resultar no solo tardía ${ }^{68}$ sino que prácticamente se limita a esta resolución, incluso cuando ya existe una jurisprudencia europea posterior que la complementa, modula y sistematiza en lo que se refiere a los criterios que integran el juicio de ponderación. Es justamente aquí, en cuanto al modo o técnica empleada para resolver esta colisión entre la libertad de expresión y la protección de la vida privada o, en nuestro caso, entre libertad de información y derecho a la propia imagen, que nuestro TC no hace suya la doctrina consolidada del TEDH, optando, como se indicará un poco más adelante, por resolver de una manera diferente. De modo tal que la afirmación que hacíamos al principio acerca de la sustancial sintonía de nuestra jurisprudencia constitucional con la del TEDH sigue siendo válida pero solo respecto de la determinación del contenido y alcance del derecho fundamental a la propia imagen de los personajes públicos en su relación dialéctica con los medios de comunicación, pero no tanto cuando se trata de establecer - o en su caso, incorporar - los criterios interpretativos conforme a los cuales resolver el conflicto así planteado y, sobre todo, la forma de hacerlo ${ }^{69}$.

${ }^{67}$ Esto no ha impedido, sin embargo, que con posterioridad a las SSTC 139/2001 y 83/2002 el TC invoque la jurisprudencia europea en relación con el derecho a la propia imagen. Es el caso de las SSTC 300/2006, FJ 2; 14/2003, FJ 5 y 23/2010, FFJJ 3 y 5 . Lo que sucede es que no solo en ninguna de ellas se cita la STEDH dictada en 2004 el caso von Hannover contra Alemania (la referencia lo es a otras sentencias del TEDH diferentes), sino que además, en ellas, salvo en la última, no se aborda directamente la determinación de si se ha producido o no la vulneración del derecho a la propia imagen de una persona de las consideradas «públicas». Y aún en la STC 23/2010 no se trata de un supuesto incardinable en el artículo 8.2.a) LO 1/1982, sino en el apartado b) de ese mismo artículo (caricatura o fotomontaje de una persona con notoriedad pública).

68 Han transcurrido 10 años desde que el TEDH dictara la sentencia que el TC cita ahora por primera vez en relación con el derecho a la propia imagen de los personajes públicos, siendo así que el propio TC desaprovecha la primera oportunidad en que pudo hacerlo en relación con este mismo supuesto: la STC 176/2013 que no contiene referencia alguna a esta STEDH. Cierto es que el adelanto en la fecha hubiera sido insignificante, apenas un año, pero sí que hubiera tenido la relevancia de tratarse de la primera ocasión en que el TC pudo incorporar la jurisprudencia europea a su propia doctrina sobre esta cuestión.

69 Confirmando así respecto de este supuesto la afirmación que, con carácter general, hiciera Queralt JiméneZ, Argelia (2008), op. cit., p. 141. 
En lo que sí coincide y es precisamente la razón por la que se invoca esta resolución de Estrasburgo, es en el relevante papel — decisivo, en el caso de nuestra jurisprudencia constitucional — que en orden a la resolución de este tipo de conflictos le corresponde desempeñar al interés público de las imágenes controvertidas $^{70}$. O, en palabras del TEDH, a si estas contribuyen a un debate de interés general ${ }^{71}$. Cuestión diferente es que haya también plena coincidencia entre ambos Tribunales en cuanto al modo en que haya de entenderse cuando concurre tal interés público, que el TEDH parece interpretar con más amplitud que nuestro $\mathrm{TC}^{72}$.

Como tampoco lo es que esta coincidencia sea absoluta. Antes al contrario, esta recepción que nuestro TC hace de esta jurisprudencia europea no es completa ni, por tanto, la sintonía total, al no extenderse al modo empleado por una y otra jurisdicción para resolver estas colisiones. Y es que, como venimos señalando, la cita se limita a la SETDH de 24 de junio de 2004, siendo así que para la fecha en la que nuestro Alto Tribunal lo hace (2014) ésta ya ha experimentado una importante evolución, plasmada en dos resoluciones de 2012, ambas de 7 de febrero: Axel Springer A. G. contra Alemania; y von Hannover contra Alemania $n .^{\circ}$ 2. En ellas, el TEDH sistematiza por primera vez los criterios que integran

70 Así, tras afirmar taxativamente el TC que el «carácter noticiable de la información se erige, por tanto, en el «criterio fundamental» (...) y «decisivo» (...) que hará ceder un derecho público subjetivo como el derecho a la imagen que se funda en valores como la dignidad humana» (STC 19/2014, FJ 6) destaca que: «También el Tribunal Europeo de Derechos Humanos, en los asuntos relativos al equilibrio entre la protección de la vida privada y la libertad de expresión, pone el acento en la contribución de la publicación de fotografías o artículos en la prensa al debate de interés general ... (por todas, STEDH de 24 de junio de 2004, caso Von Hannover c. Alemania, $\S \S 60,65,76) »($ STC 19/2014, FJ 7, cursiva añadida). En términos muy parecidos se pronuncia la STC 12/2012: «Igualmente, el Tribunal Europeo de Derechos Humanos ha destacado que el factor decisivo en la ponderación entre la protección de la vida privada y la libertad de expresión estriba en la contribución que la información publicada realice a un debate de interés general (...)» (STC 12/2012, FJ 4; cursiva añadida). No obstante, en esta sentencia y las que le siguen sobre este tema, el TC acabará desestimando que, en los casos de uso de la técnica conocida como cámara oculta, la relevancia pública de la información o reportaje audiovisual así grabado, juegue papel alguno en la medida en que «lo que está constitucionalmente prohibido es justamente la utilización del método mismo (cámara oculta)» (STC 12/2012, FJ 7).

71 «En los asuntos relativos al equilibrio entre la protección de la vida privada y la libertad de expresión que ha conocido el Tribunal, siempre ha puesto el acento en la contribución de la publicación de fotografías o artículos en la prensa al debate de interés general» (STEDH de 24 de junio de 2004, von Hannover contra Alemania, § 60).

72 Particularmente por lo que se refiere a los políticos. Véase, en este sentido, la crítica formulada por Bustos GisBert, Rafael (2016), op. cit., pp. 401-402. 
el juicio de ponderación ${ }^{73}$, muchos de los cuales ya había hecho aparición en resoluciones anteriores. Así, como primer elemento esencial, incluso determinante del resultado, el relativo a la contribución de, por lo que aquí interesa, las fotografías o documento audiovisual controvertido a un debate de interés general, que era el criterio sobre el que había girado la resolución del caso von Hannover contra Alemania en 2004. Junto a éste e íntimamente relacionado con él, el papel o la función de la persona en cuestión ${ }^{74}$ así como la naturaleza de las actividades que son objeto del reportaje o de las fotografías controvertidas y que también había sido tenido en cuenta en la resolución citada por nuestro TC. A los que se añaden ahora otros: el comportamiento previo de la persona fotografiada u objeto del reportaje escrito; el contenido, la forma y las repercusiones de la publicación; y finalmente las circunstancias en las que se tomaron las imágenes publicadas sin el consentimiento de la persona afectada. Criterios todos ellos que ya habían sido tomados en cuenta en algún momento anterior por el $\mathrm{TEDH}^{75}$. El mérito de estas resoluciones es que ahora el TEDH los sistematiza por primera vez, pasando a constituir un conjunto ordenado de reglas para la resolución de los conflictos entre la protección de la vida privada en general — no solo del derecho a la imagen - y la libertad de expresión.

A las que, sin embargo, ninguna mención hace nuestro TC. Ni a las reglas ni, obviamente, a las SSTEDH de 2012 en lo que a la sistematización de las mismas se refiere. No, desde luego en la STC 12/2012, pero tampoco en la STC 19/2014. Ni siquiera, en cuanto se refiere a los criterios de ponderación antes mencionados, en ninguna de las otras en las que el Alto Tribunal ha tenido oportunidad de pronunciarse no ya sobre el conflicto de las libertades de información y expresión con el derecho a la propia imagen, sino incluso con el derecho a la intimidad. Algo que en principio bien pudiera atribuirse a un simple desconocimiento o falta de actualización respecto de la jurisprudencia más reciente del TEDH. Si no fuera porque ningún inconveniente ha tenido nuestro TC en citar una de estas resoluciones de 7 de febrero de 2012, la dictada en el caso von

73 STEDH de 7 de febrero de 2012, Axel Springer A. G. contra Alemania, §§ 89-95; y STEDH de 7 de febrero de 2012, von Hannover contra Alemania n. ${ }^{\circ}$ 2, $\S$ 108-113.

${ }^{74}$ Lo que le lleva al TEDH a distinguir entre los particulares, por un lado, y, por otro, las personas que actúan en un ámbito público, tales como personajes públicos o políticos y cargos públicos («personalidades de la política», en la traducción al español) (Axel Springer A. G. contra Alemania, § 91; y von Hannover contra Alemania . $^{\circ} 2$, § 110).

75 Así, por ejemplo, además de los criterios relativos a la contribución a un debate de interés general o al papel y función de la persona aludida en el reportaje o fotografiada, que ya habían sido tenidos en cuenta en el caso von Hannover contra Alemania (2004), también el TEDH había tomado ya en consideración el comportamiento de la persona en cuestión en su STEDH de 2009, dictada en el caso Hachette Filipacchi Associés [ICI PARIS], §§ 52-53. 
Hannover contra Alemania $n^{\circ} 2$, para acoger, de modo similar a como el TEDH hace con la noción de vida privada, una interpretación más amplia de lo que sea la intimidad reconocida en el artículo 18.1 CE, no limitada al ámbito estrictamente doméstico o privado ${ }^{76}$.

Es por ello que entendemos que se trata más bien de una elección —o, si se prefiere, de una omisión - consciente por parte de nuestro TC de aquella jurisprudencia europea que mejor sirve a sus propósitos, que mejor se adapta a sus necesidades $y$, por tanto, a su doctrina sobre esta cuestión ${ }^{77}$.

$\mathrm{Y}$ es que, en efecto, si bien nuestro TC comparte con el Tribunal de Estrasburgo la importancia del criterio relativo al interés público de las imágenes controvertidas, difiere, sin embargo, de este en cuanto al modo concreto en que actúa como dirimente del conflicto planteado. Así, a diferencia de lo que sucede en la jurisprudencia europea en la que este criterio no es sino uno entre los varios — sin duda, el más importante y que, a la postre, puede resultar esencial_— ${ }^{78}$ que integran el juicio de ponderación, para nuestro TC se trata más bien de un elemento que sirve para delimitar el ámbito constitucionalmente protegido por las libertades de información y expresión ${ }^{79}$. El carácter noticiable, la relevancia pública de la información, en este caso en su acepción de información gráfica, formaría así parte consustancial del contenido constitucional de estas libertades, al igual que la veracidad lo es también para el derecho a la información. De este

76 «Como ha señalado el Tribunal Europeo de Derechos Humanos, existe una zona de interacción entre el individuo y los demás que, incluso en un contexto público, puede formar parte de la vida privada (Sentencia caso Von Hannover c. Alemania, Gran Sala, de 7 de febrero de 2012, $\S 95)$. Así lo hemos reconocido también en nuestra doctrina, por cuanto hemos afirmado que "la intimidad protegida por el artículo 18.1 CE no se reduce necesariamente a la que se desarrolla en el ámbito doméstico o privado". (STC 12/2012, de 30 de enero, FJ 5)». (SSTC 7/2014, FJ 4 y 18/2015, FJ 5). La misma idea está también presente en la STC 12/2012, si bien en ella no se cita esta STEDH, aunque sí otras del TEDH.

77 Teniendo en cuenta que, como se ha afirmado con acierto, «no se conoce la causa concreta que en cada caso lleva a una Sala o al Pleno a apoyar de manera más o menos intensa sus argumentaciones jurídicas en los instrumentos europeos»[Queralt Jiménez Argelia (2008), op. cit., p. 211]. Si esto es así cuando el TC sí usa la jurisprudencia del TEDH, con más razón aún en los casos en los que no lo hace. Sólo cabe aventurar la razón, pero sin pretensión alguna de certeza al respecto.

78 Así lo ha llegado a calificar («criterio esencial») el propio TEDH en su sentencia de 4 de diciembre de 2012, caso Rothe contra Austria, § 54.

79 En un sentido diferente, Gómez CoRONA para quien la relevancia pública se convierte en un elemento delimitador no propiamente de las libertades de información y expresión, sino «del derecho a la propia imagen, que únicamente puede esgrimirse en ausencia de aquella.» [GómEz Corona, Esperanza (2014), La propia imagen como categoría constitucional, Cizur Menor, Aranzadi, p. 118].

N.o 100 , septiembre-diciembre 2017, págs 441-480 
modo, frente a la ponderación como método de resolución de este tipo de conflictos nuestro TC ha acabado decantándose por llevar la resolución de estos conflictos al terreno de la delimitación, inclinándose no tanto por ponderar como por tratar de realizar una adecuada y precisa delimitación de los derechos implicados: propia imagen y libertades de información o expresión; particularmente, de estos últimos ${ }^{80}$. De lo que se sigue que el TC parece descartar, no ya que

$80 \mathrm{Si}$ —como ha señalado Villaverde MenéndeZ - las «técnicas de resolución de los conflictos entre derechos fundamentales (ponderación, concordancia práctica, razonabilidad, cláusula de comunidad, proporcionalidad) pueden reconducirse fácilmente a dos: ponderación de bienes o la delimitación de los derechos en presencia» [VILlaverde Menéndez, Ignacio (2008), «La resolución de conflictos entre derechos fundamentales. El principio de proporcionalidad», en CARbonell, Miguel (ed.), El principio de proporcionalidad y la interpretación constitucional, Quito, Ministerio de Justicia y Derechos Humanos, p. 176], cabe considerar al TEDH y al TC como exponentes de una y otra técnica: ponderación versus delimitación, recíprocamente, y eso aun cuando en esta misma STC 19/2014 el TC no renuncia a seguir empleando el término "ponderación». También se pronuncia en este sentido, acerca del empleo por el TC de la técnica de la delimitación de derechos, particularmente en relación con las libertades del artículo $20 \mathrm{CE}$ aun cuando siga hablando en numerosas ocasiones de «ponderación», ViLLAVerde Menéndez, Ignacio (2008), «Artículo 20.1.A) y D), 20.2, 20.4 y 20.5. La libertad de expresión», en CaSAS BAamonde, María Emilia y Rodríguez-PiÑero y Bravo-Ferrer, Miguel (dirs.), Comentarios a la Constitución Española, Madrid, Fundación Wolters Kluwer, p. 475. Ya en 2004 SÁnCHEZ FERriz abogaba por una clara delimitación del ámbito protegido por la libertad de expresión y el derecho a la información, como paso previo necesario antes de dilucidar si, excediendo de dicho ámbito, se ha podido invadir la esfera de un derecho ajeno, en la consideración, además, de que al actuar de este modo, los eventuales conflictos entre derechos no serían tantos o, al menos, su resolución sería o debería ser más fácil ya que se comenzaría por saber si estas libertades se han ejercido o no legítimamente. Algo que a juicio de la autora y en el caso del derecho a la información requiere no solo de la veracidad sino también de la relevancia pública de la información [SÁnCHEz FERriz, Remedios (2004), Delimitación de las libertades informativas, Valencia, Tirant lo Blanch]. También Presno Linera se ha pronunciado en contra de la técnica de la ponderación y a favor de la delimitación de derechos, particularmente respecto de los conflictos de derechos que no son tales, sino solo «aparentes» por cuanto que el conflicto, de existir, lo sería entre el derecho y sus límites [PRESNO Linera, Miguel Ángel (2016), «Una crítica al uso de la teoría de la ponderación en los conflictos (aparentes) entre derechos fundamentales», VV. AA., Liber amicorum: homenaje al profesor Luis Martínez Roldán, Oviedo, Ediuno; disponible en https://presnolinera.files.wordpress. com/2016/09/una-crc3adtica-al-uso-de-la-teorc3ada-de-la-ponderacic3b3n-en-los-conflictosaparentes-entre-derechos-fundamentales.pdf]. La misma idea la encontramos también en Bastida Freijedo, Franciso J. y otros (2004), Teoría general de los derechos fundamentales en la Constitución Española de 1978, Madrid, Tecnos, pp. 141-145. Esto sería justamente lo que ocurriría en el caso que nos ocupa, en el que el límite a las libertades de expresión e información, la propia imagen (art. 20.4 CE) es, también y a su vez, un derecho fundamental con contenido propio (art. 18.1 CE). Bastante crítico con este apartamiento de nuestra jurisdicción constitucional respecto al método ponderativo empleado por el TEDH para resolver este tipo 
deban gozar de una protección constitucional prevalente, sino incluso que gocen de protección constitucional alguna aquellas informaciones, en este caso imágenes, en las que no concurra una relevancia pública suficiente ${ }^{81}$. Lo que, no obstante, aún dejaría sin resolver cuánta relevancia pública es suficiente —en el sentido de necesaria — para que la difusión mediática no consentida de la imagen pudiera entenderse amparada como ejercicio legítimo del derecho a la información $^{82}$.

de conflictos se ha mostrado Bustos GisBert, Rafael (2016), op. cit., pp. 407 y ss. También crítico pero, en este caso, respecto del modo en que el TC ha recepcionado la doctrina norteamericana sobre la posición preferente (preferred position) de la libertad de expresión y la combina con la técnica de la ponderación circunstancial, Ángel RoDRíguEz, quien destaca cómo el uso que este hace de dicha ponderación lo es, principalmente, en su modalidad de ad hoc balancing, de modo tal que en vez de que sea la constatación de que la libertad de expresión se ha ejercido con posición preferente — consecuencia de la existencia de interés público en el mensaje controvertido - la que guíe la ponderación de circunstancias (principled balancing), resulta ser, por el contrario, el resultado al que se llega tras dicha ponderación. Esta es, a juicio del autor, «la principal razón por la que la doctrina de la posición preferente no ha podido servir en España de pauta para la ponderación circunstancial, y de que sea en el seno de ésta donde se siga encontrando, casi siempre, la auténtica ratio decidendi del TC.» [RoDríGuez, Ángel (2016), op. cit., pp. 246 y ss., en particular p. 251].

81 Así, frente a los términos empleados en la STC 83/2002, FJ 5 («tampoco puede estimarse que la difusión de las controvertidas fotografías estuviera amparada en un interés público constitucionalmente prevalente»; cursiva añadida) desaparece ahora toda alusión al carácter prevalente de dicha protección constitucional que resulta, pues, simplemente inexistente al carecer de la relevancia pública necesaria para que pueda entenderse amparada, sin más adjetivo ni condición, en el derecho fundamental a la información ( «De todo lo anterior se concluye que las fotografías publicadas carecían de la relevancia pública necesaria para que la revista pudiera ampararse en el derecho fundamental a comunicar libremente información», STC 19/2014, FJ 9). Cabe recordar, no obstante, que el TC, ya desde sus primeras resoluciones sobre la libertad de información, tenía establecido que este derecho versa no ya solo sobre información que pueda estimarse veraz, sino «más restringidamente, solo sobre aquellos hechos que puedan considerarse noticiables», en el sentido de "“que puedan encerrar trascendencia pública", a efectos de que "sea real la participación de los ciudadanos en la vida colectiva" (STC 6/1988, FJ 5, con cita de extracto extraído de la STC 105/1983, FJ 11). Para un análisis del impacto de estas resoluciones en la funcionalización de las libertades comunicativas en aras de la formación de una «opinión pública libre» y, por tanto, de la institucionalización de ésta, véase Rodríguez, Ángel (2016) ibídem., pp. 33 y ss.; y Villaverde Menéndez, Ignacio (2008), «Artículo 20.1. A) Y D), 20.2, 20.4 y 20.5. La libertad de expresión», cit, en particular pp. 473-474.

${ }_{82}$ Sobre esta cuestión, a partir de la idea que la noción de interés público no es estática, sino dinámica, susceptible de gradación en función de las circunstancias concurrentes, véase NAVAS SÁNCHEZ, María del Mar (2017), op. cit., pp. 8 y 32-36. 
Por lo demás, mucho más profusa, frecuente y temprana ha sido el uso que por nuestra jurisdicción ordinaria, Tribunal Supremo incluido, se ha hecho de esta misma jurisprudencia europea ${ }^{83}$. Lo que no ha impedido, sin embargo, que el protagonismo haya recaído igualmente en la STEDH de $2004^{84}$. Ni tampoco ha supuesto, como hemos tenido ocasión de comprobar en las páginas precedentes, que esta incorporación del canon europeo por la jurisprudencia ordinaria se haya realizado de manera correcta. Particularmente por lo que se refiere a la noción de «vida privada», a la que hasta hace bien poco se le venía atribuyendo un relevante papel en la resolución de este tipo de conflictos relativos al derecho a la propia imagen de los personajes públicos.

83 Así cabe citar la STS 789/2008, de 24 de julio, como la primera en la que el TS cita la STEDH de 24 de junio de 2004 (von Hannover contra Alemania) siendo desde entonces innumerables las ocasiones en las que este Tribunal se va a referir a la misma, en un fórmula ritual que se repite de manera prácticamente constante (SSTS 1233/2009, de 16 de enero; 400/2009, de 12 de junio; 611/2009, de 7 de octubre; 719/2009, de 16 de noviembre; 442/2010, de 8 de julio; 756/2010; 757/2010; 811/2010, de 16 de diciembre; 830/2010, de 17 de diciembre; 92/2011, de 25 de febrero; 166/2011, de 14 de marzo; 179/2011, de 18 de marzo; 169/2011, de 21 de marzo; 169/2011, de 23 de marzo; 272/2011, de 11 de abril; 284/2011, de 11 de abril; 281/2011, de 25 de abril; 378/2011, de 6 de junio; 469/2011, de 15 de junio; 471/2001, de 15 de junio; 470/2011, de 15 de junio; 452/2011, de 28 de junio; 437/2011, de 29 de junio; 525/2011, de 30 de junio; 458/2011, de 30 de junio; 548/2011, de 11 de julio; 539/2011, de 18 de julio; 590/2011, de 29 de julio; 602/2011, de 29 de julio; 583/2011, de 6 de septiembre; 702/2011, de 5 de octubre; 733/2011, de 10 de octubre; 909/2011, de 30 de noviembre; 928/2011, de 12 de diciembre; 5/2012, de 19 de enero; 6/2012, de 23 de enero; 57/2012, de 13 de febrero; 96/2012, de 20 de febrero; 89/2012, de 29 de febrero; 201/2012, de 26 de marzo; 264/2012, de 18 de abril; 270/2012, de 19 de abril; 311/2012, de 7 de mayo; 441/2012, de 29 de junio; 402/2013, de 10 de junio; 561/2013, de 30 de septiembre; 803/2013, de 10 de diciembre; 796/2013, de 17 de diciembre; 806/2013, de 7 de enero de 2014; 816/2013, de 9 de enero de 2014; 23/2014, de 17 de enero; 405/2014, de 10 de julio; 471/2014, de 17 de septiembre; 485/2016, de 14 de julio; 547/2016, de 19 de septiembre). Incluso ha recepcionado también la STEDH de 7 de febrero de 2012 (von Hannover contra Alemania n. ${ }^{\circ}$ 2), a la que cita en las SSTS 411/2014, de 23 de julio; 436/2014, de 28 de julio y 471/2016, de 12 de julio. Por su parte Bustos GisBert ha señalado la sentencia dictada por el Juzgado de Primera Instancia número 21 de Barcelona de 2 de diciembre de 2004 como la primera en que se utiliza por la jurisdicción ordinaria la jurisprudencia sentada en 2004 por el TEDH en el caso von Hannover, destacando cómo la recepción de esta jurisprudencia europea se ha producido «de abajo hacia arriba», es decir, «desde los tribunales de primera instancia hasta las más altas instancias jurisdiccionales.» [BUSTOS GisBERT, Rafael (2016), op. cit., pp. 381-382].

84 Así, como hemos visto en la nota anterior, frente a la abundancia de citas de la sentencia dictada por el TEDH en 2004 en el caso von Hannover, el TS se ha referido a la STEDH de 7 de febrero de 2012 (von Hannover contra Alemania $n .^{\circ}$ 2) en muchas menos ocasiones; concretamente en las SSTS 411/2014, de 23 de julio; 436/2014, de 28 de julio y 471/2016, de 12 de julio. 


\section{CONCLUSIONES}

El recorrido realizado por las jurisprudencias constitucional, ordinaria (en el ámbito civil) y europea sobre uno de los aspectos más controvertidos del derecho fundamental a la propia imagen en su interacción con los medios de comunicación —el relativo a quienes, de manera amplia, pueden ser considerados personajes públicos — nos ha permitido observar, por un lado, el modo en que este supuesto concreto viene siendo resuelto por los Tribunales implicados (Constitucional, Supremo y de Estrasburgo) y, de otro, las diferentes relaciones que a lo largo de este tiempo se han ido estableciendo entre dichas jurisprudencias.

Así por lo que se refiere a la primera de las cuestiones hemos constatado la importante evolución que en nuestro ordenamiento jurídico ha experimentado el régimen jurídico de este derecho (la propia imagen) en este supuesto concreto (personajes públicos) desde que nuestra Constitución de manera novedosa reconociera por primera vez el derecho a la propia imagen como un derecho fundamental autónomo en su artículo 18.1. Se trata, además, de un proceso en el que el Tribunal Constitucional ha desempeñado un papel destacado en detrimento del que a lo largo de este tiempo han jugado también otros actores destacados en la configuración de este régimen: el Tribunal Supremo y, particularmente, el legislador de los derechos fundamentales. Y es que, en efecto, y a diferencia de lo sucedido en el caso de la jurisdicción ordinaria, nuestro Tribunal Constitucional no se ha mostrado especialmente vinculado por la decisión que en su día y a propósito de este supuesto conflictual, tomara el legislador a favor de los medios de comunicación y los derechos a la libertad de expresión e información subyacentes, plasmada en el artículo 8.2. a) LO 1/1982.

De este modo, frente a lo dispuesto en la norma legal, que interpretada de manera literal — como, con ciertos matices, venía haciendo habitualmente el Tribunal Supremo - legitima cualquier difusión mediática de la imagen (fotografía, documento audiovisual) de una persona pública siempre que esta haya sido captada en un lugar abierto al público, el Tribunal Constitucional ha optado desde un primer momento por conformar el canon de enjuiciamiento a partir de otros parámetros extraídos directamente de los preceptos constitucionales en liza (arts. 18.1 y 20.1 CE). En un proceso, a su vez, en el que hemos diferenciado dos etapas claramente diferenciadas y en la que el Alto Tribunal ha terminado por erigir al interés público presente en las imágenes controvertidas, a su carácter noticiable, en el elemento decisivo conforme al cual determinar la legitimidad —o no- de su difusión al amparo de las libertades informativas con el consiguiente sacrificio del derecho personal del sujeto efigiado. 
Al trascender lo dispuesto en la Ley y operar conforme a categorías propiamente constitucionales no solo termina el Tribunal Constitucional por aplicar a la propia imagen el mismo régimen jurídico que ya tenía establecido en relación con los derechos al honor y a la intimidad en su relación con los medios de comunicación sino que, además, refuerza la protección del derecho a la propia imagen de quienes, como los personajes públicos, se ven habitualmente más expuestos a los excesos de un cierto tipo de prensa («rosa» o «del corazón») que encuentran en ellos un importante filón mediático. Eliminando así, de raíz, la cobertura que la misma había encontrado en la más permisiva jurisprudencia del Tribunal Supremo e invirtiendo, sin declaración alguna de inconstitucionalidad sino tan solo apelando a su interpretación conforme a la Constitución, la opción que en su día hiciera el legislador hasta el punto de privarla, en la práctica, de sentido.

Pero, además, y esto nos lleva a la segunda de las cuestiones apuntadas al principio de este epígrafe, esta jurisprudencia constitucional no difiere sustancialmente de la que se sostiene sobre este mismo supuesto por el Tribunal Europeo de Derechos Humanos. Al menos por lo que se refiere al contenido y alcance del derecho a la propia imagen de este tipo de personas, derecho que en el caso del estándar europeo se integra, como un aspecto del mismo, en el más amplio derecho a la protección de la vida privada (art. 8.1 CEDH). Así, el análisis que hemos realizado de las principales resoluciones de una y otra jurisdicción sobre este supuesto nos ha llevado a concluir que, no obstante el escaso uso que del canon europeo ha hecho nuestro Tribunal Constitucional — sobre todo en la que hemos fijado como primera etapa jurisprudencial—, esta interpretación constitucional es sustancialmente conforme con la del Tribunal de Estrasburgo (art. 10.2 CE). En lo que, como ya hemos indicado, tiene que ver con el contenido y alcance de este derecho respecto de las libertades de expresión e información. No así, sin embargo, en lo atinente a la técnica o método empleado por una y otra jurisdicción para resolver el conflicto a este respecto planteado. Así, mientras que el Tribunal Europeo de Derechos Humanos se adhiere claramente a la ponderación —con sistematización de criterios incluida - como método de resolución de este tipo de conflictos, nuestro Tribunal Constitucional ha acabado decantándose por llevar su enjuiciamiento al terreno de la delimitación, inclinándose no tanto, a pesar de seguir utilizando la terminología, por ponderar como por tratar de realizar una adecuada y precisa delimitación de los derechos implicados: propia imagen pero, sobre todo, libertades de expresión e información. De lo que se sigue que el Tribunal Constitucional parece descartar, no ya que deban gozar de una protección constitucional prevalente, sino incluso que gocen de protección 
constitucional alguna aquellas informaciones o, por lo que aquí interesa especialmente, imágenes, en las que no concurra una relevancia pública suficiente.

En cualquier caso, esta situación de relativa sintonía de nuestra jurisprudencia constitucional con la europea contrasta con la mantenida a propósito del supuesto objeto de este estudio por la jurisdicción ordinaria, mucho más controvertida y caracterizada durante muchos años por su profunda divergencia con la doctrina al respecto del Tribunal Constitucional. Una situación en la que, por lo demás, ha tenido mucho que ver la existencia de una norma como la prevista en el artículo 8.2.a) LO 1/1982 a la que, salvo excepciones y con las precisiones indicadas en el texto, se ha atenido de manera rigurosa el Tribunal Supremo.

Será solo tras la STC 19/2014, clave en el derecho que nos ocupa, cuando sea posible afirmar, aún a riesgo de equivocarse dada la poca perspectiva que proporciona el escaso tiempo transcurrido desde entonces, que esta brecha ha empezado a cerrarse. Como resultado de la pacífica, explícita y, en líneas generales, adecuada, a diferencia de lo sucedido con anterioridad, asunción por la jurisdicción ordinaria de la doctrina del Tribunal Constitucional acerca del alcance del derecho a la propia imagen de este tipo de personas frente a la publicación inconsentida de imágenes de los mismos en los medios de comunicación y, en consecuencia, respecto a cómo ha de interpretarse la LO 1/1982 y más concretamente el precepto que regula este supuesto. Es en este sentido que hemos afirmado que la distancia que, en punto a esta cuestión, separa a ambos Tribunales - Constitucional y Supremo- es la que media entre el artículo 8.2.a) LO 1/1982 y la recepción por el Tribunal Supremo de la interpretación conforme a la Constitución que de este precepto legal se contiene en la STC 19/2014.

Title:

The right to their own image of public figures in the Constitutional, Ordinary and European Case-Law. Evolution, concordances and divergences.

\section{Summary:}

1. Introduction. 2. The little, but adequate, express influence of the european canon in the first constitutional case law on the fundamental right to own's image. 3. The fundamental right to their own image of public figures in the constitutional case law prior to STC 19/2014. 
Its almost null follow-up by the supreme court. 4. The fundamental right to their own image of public figures in the latest constitutional case law. Its - now yes - reception by the supreme court. 5. The relationship of constitutional case law with that of the European Court of Human Rights on this specific right, seen through STC 19/2014. 6. Conclusions.

\section{Resumen:}

Este artículo aborda el probablemente más controvertido supuesto relativo a la relación dialéctica entre las libertades de expresión e información y el derecho fundamental a la propia imagen. El que tiene como titular de este último derecho a quien puede ser considerado, en general, como un personaje público. Lo hace, además, desde una doble perspectiva. Por un lado, se muestra la evolución experimentada en el régimen jurídico del derecho a la propia imagen de este tipo de personas desde que en 1978 y de manera novedosa nuestra Constitución reconociera por vez primera el derecho a la propia imagen como un derecho fundamental autónomo y diferenciado de la intimidad en el artículo 18.1 CE hasta nuestros días. Se trata de un proceso que ha venido marcado por varios hitos: la aprobación en 1982 de una norma (la Ley Orgánica 1/1982, de 5 de mayo, de protección civil del derecho al honor, a la intimidad y a la propia imagen) en la que el legislador establece pautas muy concretas acerca del modo en que han de resolverse este tipo de conflictos; la intensidad con la que esta Ley ha condicionado la jurisprudencia de los jueces y tribunales de la jurisdicción ordinaria, particularmente del Tribunal Supremo; y, finalmente, el importante papel desempeñado por la jurisprudencia del Tribunal Constitucional que, prescindiendo de las prescripciones legislativas y operando conforme a categorías constitucionales, ha terminado por erigir, en un proceso que, a su vez, hemos diferenciado en dos etapas, al interés público presente en las imágenes controvertidas, en el elemento decisivo para resolver este tipo de conflictos. Pero por otro, además, se presta especial atención a las recíprocas relaciones que a propósito de este supuesto se han establecido a lo largo de estas décadas entre las jurisprudencias de los Tribunales Constitucional, Supremo y de Estrasburgo. En este sentido, nos ha parecido especialmente interesante fijarnos no solo en el modo en que el Tribunal Constitucional se ha servido del canon europeo (art. 10.2 CE) para construir su propia doctrina sobre el derecho fundamental a la propia imagen de los personajes públicos, sino también y muy particularmente, en la forma en que esta doctrina del Tribunal Constitucional ha sido seguida o no por el Tribunal Supremo y, por tanto, en el modo 
en que este último se ha sentido vinculado, si es que lo ha hecho, a la misma, dando así cumplimiento a su obligación constitucional (art. 5.1 LOPJ).

\begin{abstract}
:
This paper tackles the probably more controversial case concerning the dialectical relation between the freedoms of expression and information and the fundamental right to the own image. The one that refers to so-called «public figures». It does so from a dual perspective. On the one hand, it shows the evolution experienced in the right to their image of this type of people since Spanish Constitution, in 1978, recognized for the first time the right to own image as a fundamental right autonomous and different from the right to a private life (art. 18.1) to the present day.

This is a process that has been marked by several landmarks: the adoption in 1982 of a rule (Organic Law 1/1982, of May 5, on civil protection of the right to reputation, privacy and own image) in which the legislator lays down very specific guidelines as to how such conflicts should be resolved; the intensity with which this Law has conditioned the case law of judges and courts of ordinary jurisdiction, particularly the Supreme Court; and finally, the important role played by the case law of the Constitutional Court, which, regardless of the legislative requirements and taking constitutional categories as references, has finally established, in a process that we have differentiated in two stages, the public interest of the images (or, in other words, the contribution made by photos to a debate of general interest) in the decisive element to solve this type of conflicts.

But on the other hand, special attention is also paid to the reciprocal relations that have been established over these decades among the case law of the Constitutional, Supreme and Strasbourg Courts. On this regard, we have found particularly interesting to look not only at the way in which the Constitutional Court has used the jurisprudence of the European Court of Human Rights (Article 10.2 Spanish Constitution) to establish its own doctrine on the fundamental right to their image of public figures, but also, especially, in the way in which this doctrine of the Constitutional Court has been followed or not by the Supreme Court and therefore if the latter has fulfilled its constitutional obligation (Article 5.1 Organic Law of the Judiciary).
\end{abstract}


Palabras clave:

Derecho fundamental a la propia imagen, personajes públicos, libertades de expresión e información, medios de comunicación, vida privada, diálogo judicial.

\section{Key words:}

Fundamental right to own's image; public figures; freedom of speech and information; mass media; privacy; judicial dialogue. 